\title{
Bir Çekim Merkezi Olarak Arktika'nın Çin Ekonomisi Açısından Önemi: Seçilmiş Endüstrilere Yönelik Bazı Çıkarımlar
}

The Importance of the Arctic Region as a Centre of Attraction for the Chinese Economy: Some Implications for Selected Industries

Mehmet ZANBAK ${ }^{1}$

A. Beyhan AKAY2

Geliş tarihi: 31.05.2019, Kabul tarihi: 26.06.2019, Basım tarihi: 25.10.2019

Öz

Büyüme performansı bakımından küresel ölçekte en önde gelen ülkelerin arasında yer alan Çin, bu performansı sürekli kılabilmek adına son dönemlerde yeni arayışlara girmiștir. Bu süreç içerisinde küresel 1sınmanın buzulları eritmesi, dünyanın kuzey ucunda yer alan Arktika bölgesinin ekonomik potansiyelini ortaya çıkarmış, Çin ise bu pastadan pay alabilmek adına bölgeye ilgisini sürekli arttırmışır.

Buzulların erimesiyle birlikte Kuzey Arktika deniz yolu; taşımacilığı, madenciliği, petrol ve doğalgaz gibi enerji kaynaklarını öne çıkarmış ve birçok ülke gibi Çin de bu konudaki yatırımlarını bölgede yoğunlaştırmıştır. Bu çalışma, özellikle Avrupa-Asya ticari denizyolu mesafesinin önemli ölçüde kısalmasını sağlayan bu koridorun, enerji kaynaklarının ve değerli madenlerin, Çin ekonomisinin gelişmesindeki önemini ortaya koymayı amaçlamaktadır.

Anahtar Kelimeler: Arktika, Çin, Kuzey Ticaret Rotasi, Arktika enerji kaynaklar ve madenciligi.

JEL Kodlar1: F18, F21.

\begin{abstract}
China, which is among the leading countries on the global scale in terms of growth performance, has recently entered into new searches to sustain this performance. In this process, the melting of the glaciers of global warming has revealed the economic potential of the Arctic region at the northern end of the World, and China has increased its interest in the region in order to get a share of this cake.

With melting glaciers, North Arctic maritime transport, mining, energy resources such as oil and natural gas became important and China, like many other

\footnotetext{
1 Akdeniz Üniversitesi, İ̈BF, Ekonometri Bölümü, Dr.Öğr. Üyesi, mehmetzanbak@akdeniz.edu.tr https:/ / orcid.org/0000-0002-9838-9063

2 Akdeniz Üniversitesi, Uygulamalı Bilimler Fakültesi, Uluslararası Ticaret ve Lojistik Bölümü, Dr.Öğr.Gör.

beyhanyilmaz@akdeniz.edu.tr

https://orcid.org/0000-0002-0749-6606
} 
countries, has concentrated its investments in the area. In this study, it is aimed to reveal the importance of the corridor which significantly shortens the maritime trade distance between the Europe and Asia, energy resources, and precious metals in the development of Chinese economy.

Keywords: Arctic, China, North Trade Route, Arctic energy resources and mining.

JEL Codes: F18, F21.

\section{Giriş}

Kutup dairesinin çevresinde bulunan ve içerisinde Kanada, Rusya, ABD, Norveç ile Danimarka (Grönland yoluyla) beşlisinin yer aldığ1 bölge Arktika $a^{3}$, bu ülkelerle birlikte sonradan katılanların oluşturduğu ve işbirliği amaçlı kurumsal kimliğe kavuşan organizasyon Arktika Konseyit olarak adlandirılmaktadır. Bu Konsey, Arktika ülkelerinin daimi üyeliği ile bölgedeki yerel unsurların oluşturduğu organizasyonların 6'sının daimi üyeliğini bünyesinde barındırırken, bunun yanında Konsey'de 12 devlet ve 20 uluslararas1 organizasyon, gözlemci üye statüsünde bulunmaktadır (Demirkıllı̧ ve Pehlivanl1, 2016: 253-254). İşbirliği temelinde Arktika'nın geleceğini inşa etme hedefi olan bu Konsey’in Mayıs 2013 Bakanlar Toplantısı'nda, içerisinde Çin’in de bulunduğu, İtalya, Japonya, Hindistan, Singapur ve Güney Kore'den oluşan altı ülke, daimi gözlemci olarak kabul edilmiş bulunmaktadir ${ }^{5}$ (Tonami, 2014: 105; Huang vd., 2015: 62).

Eşsiz bir doğal çevreye ve zengin kaynaklara sahip olan Arktika, yakın zamanda hızlı bir değişim sürecinden geçmektedir. Geçtiğimiz otuz yıl boyunca, Kuzey Kutbu'nda sürekli artan sicaklık yaz aylarında deniz buzunun azalmasına neden olmaktadır. Bilim adamları, bu yüzyılın ortalarında, hatta daha erken bir zamanda, kutup okyanusunda y1lin bir bölümünde buz olmayacağını tahmin etmektedir. Bu süreç, bir yandan deniz seviyesinde yükselme, aşırı hava olaylarında artış, biyolojik çeşitlilik hasarı gibi ekosistemde geri dönüşü olmayan değişikliklere yol açarken, diğer yandan bölgenin gelişimi için koşullar değişmekte, deniz yollarının ticari kullanımı ve bölgedeki kaynakların geliştirilmesi için firsatlar sunmaktadır.

\footnotetext{
${ }^{3}$ EK 1'de yer alan harita, Arktika'nın coğrafi konumu ve sınırlarına ilişkin okuyucuya fikir verecektir.

${ }_{4}$ ABD, Kanada, Danimarka, İzlanda, Norveç, İsveç, Finlandiya ve Rusya konseyin daimi üyeleridir (Arctic Coincil, 2013: 4).

51996 yllında kurulan Arktika Konseyi'nin diğer gözlemci ülkeleri; 1998'de Almanya, Hollanda, Polonya ve Birleşik Krallık; 2002'de Fransa; 2006'da İspanya'dır (Tonami, 2014: 105; Huang vd., 2015: 62). Ayrıca 2013’ten önce sadece Avrupa ülkelerine daimi gözlemcilik hakk1 verilirken, bu tarihten sonra Asya ülkeleri de Konsey'e dahil edilmiş ve böylelikle Arktika Konseyi küresel bir statü kazanmıştır (Demirkılıç ve Pehlivanlı, 2016: 253-254).
} 
Bölgedeki ticari faaliyetler, küresel deniz taşımacıllı̆ı, uluslararası ticaret ve enerji arzı üzerinde önemli etkilere sahip olurken, sosyal ve ekonomik değişimleri beraberinde getirecek ve yerli halklar da dahil olmak üzere Arktika sakinlerinin çalışma ve yaşam tarzı üzerinde de etkili olacaktır. Bu ticari faaliyetler şüphesiz Kuzey Kutup Bölgesi'nin ekolojik bütünlüğü için potansiyel bir tehdidi de bünyesinde barındırmaktadır (The State Council, 2018: 2). Küresel ısınmanın hızını arttırmasıyla gelişen bu süreç içerisinde, içe dönük zayıf bir ekonomiden, dünyanın en büyük ihracatçısına dönüşen Çin'in ${ }^{6}$ küresel ilgisi, denizaşı1ı enerji ve hammadde arzına olan yoğun bağımlılı̆̆ı nedeniyle hızla artmaktadır (Lanteigne, 2014: 7). Piyasaya yönelik bir sistemi benimsediğinden beri Çin, dış ticarete giderek daha fazla bağımlı hale gelmiş; ithalat ve ihracatın etkisi, Çin toplumunda ve ekonomik uygulamalarında derinlemesine yer etmiştir. Bu durum yurtdışı tüketici pazarlarına ve üreticilerine olan güven, nakliye rotası ve liman altyapısının Pekin için büyük öneme sahip olduğu anlamına gelmektedir. Ayrıca Çin’in küresel liderliği için sürdürülebilir ekonomik büyüme, ulusal güvenlik önceliği kadar önemli görülmektedir. Bu nedenle, Çin artık yeni ticari yollar aramakta ve bu düşünce Kuşak ve Yol Girişimi'nde kilit bir rol oynamaktadır. Bu noktada küresel iklim değişikliği, Çinli planlamacılara yeni ticaret rotaları geliştirmek için ilginç seçenekler sunmaktadır. Bir başka ifadeyle iklim değişikliğinin küresel ekosistem için çok ciddi ve yıkıcı sonuçları olmasına rağmen, deniz ticaretinde yeni firsatlar yaratması da beklenmektedir (Descamps, 2019: 1).

Özellikle son yirmi yılda, Çin ile zengin kaynaklara sahip kıtalar arasındaki ilişkiler, Çin'in bu bölgelere artan ilgisi ve ucuz Çin ürünleri ile hammadde arasında ekonomik tamamlayıcllık ilişkisi, Çin'in benzeri görülmemiş bir ekonomik ve politik önem düzeyine ulaşmasını sağlamıştır. Diğer yandan dünyanın çeşitli yerlerinden gelen emtia arzını genişletme ve çeşitlendirme çabalarına rağmen, uzun vadede Çin'in sürdürülebilir kalkınması; enerji ve doğal kaynak kıtlığı, astronomik ekonomik ölçeği, dünya ortalaması altında olan kişi başına kaynak rezervi ve mevcut hammaddeleri etkin kullanamamasi gibi nedenlerden ötürü büyük bir darboğaz tehdidi ile karşı karşıyadır (Chen, 2012: 361). Bununla birlikte 2008 küresel finansal krizi ve ardından yaşanan durgunluklar ile Batı'daki yavaş toparlanmalar, Çin ihracatını olumsuz etkilemesine karşın, gayri safi yurtiçi hasıla büyüme hızının Batı standartlarına göre daha yüksek gerçekleşmesinin önüne geçememiştir. Bununla birlikte, hem Çin için hem de küresel olarak "sert iniş" senaryosuyla ilgili süregelen bir endişe de mevcuttur. Zira Çin ekonomisi, ABD ve Avrupa gibi kilit pazarlardaki Çin mallarına olan talebin azalması nedeniyle yavaşlyyor olsa da, Pekin, yavaşlama sürecini yönetmeyi,

${ }^{6} \mathrm{Bu}$ noktada Çin'in, Amerika Birleşik Devletleri'nin ardından dünyanın en büyük ikinci ekonomisi olmasına rağmen, halen gelişmekte olan ülkeler sınıfina dahil olduğu da belirtilmelidir. 
yerel düzeyde ekonomik büyümeyi teşvik etmeyi ve en azından sınırlı ekonomik bozulma ile büyümeyi yavaşlatan "yumuşak iniş" sürecini öngörmektedir (Lanteigne, 2014: 7). Bu nedenle Çin ekonomisi yalnızca Batı'yla, özellikle de ABD ve Avrupa'yla yapılan ticaretin sürdürülmesine değil, aynı zamanda enerji ve hammaddenin sürekli akışına bağlı olarak da büyümeyi hedeflemektedir. Bu doğrultuda da, dünyanın en büyük petrol ithalatçısı ülkelerinden biri olarak Çin, tercihen erişilebilir ve politik olarak istikrarlı bölgelerde, yeni petrol ve doğalgaz kaynakları bulma konusunda çalışmalarını sürdürmektedir. Batı ve Çin arasındaki siyasi ve ekonomik rekabet, iklim değişikliği sonucu ortaya çıması beklenen kaynaklar nedeniyle Kuzey Kutbu da dahil olmak üzere, dünyanın pek çok bölgesinde artmaktadır. Gelinen noktada Arktika ve Uzak Kuzey bölgeleri, fosil yakıtların yanı sıra, adi ve değerli metaller, mineraller ve değerli taşlar da dahil olmak üzere hammaddelere erişimin kolaylaşması nedeniyle, dünyanın egemen küresel güçleri gibi Çin ve Asya'nın diğer bölgeleri için de ekonomik olarak değerli olarak görülmektedir?

Arktika’nın Çin özelindeki öneminin ve potansiyelinin irdelendiği bu çalışmanın ilk bölümünde, Arktika’nın ekonomik yapısı ele alınmaktadır. Hızlı iklim değişikliği ile birlikte ulaşılabilirliği artan ve adeta "değerli maden cenneti" olarak nitelendirilen bölgeye ait Çin politikaları çalışmanın ikinci bölümünü oluşturmaktadır. Bu bölüm içerisinde Çin'in deniz yolu taşımacılığı, enerji ve bölgedeki yatırımları irdelenmektedir. Çalışmanın üçüncü bölümünde Arktika’nın geleceğine yönelik bazı tahminler ve Çin'in

7 Uluslararası firmaların Arktika'da faaliyet göstermesine ilişkin literatürde çeşitli SWOT analizlerine rastlanmaktadır. Yapılan bu analizlerin küresel firmalara, piyasaya, taşımacılık sektörüne ve çevreye yönelik ortak noktaları şu şekilde özetlenebilir; güçlü yönler, çeşitlendirilmiş işletmeler, büyük limanlara erişim, daha az yakıt kullanımı, daha az kirlilik, daha az deniz trafiği, yeni kaynaklara erişim, hızlı teslimat, güçlü araştırma geliştirme yeteneği, çeşitlendirilmiş coğrafi yap1, garanti/yüksek gelir ve kar, kuzey güney iletişim artışı, işbirliklerinde artış; zayıf yönler, sert iklim koşulları, geçiş planlarının pahalılı̆̆ı, yerel halkın göçü, sadece belirli sınıf gemilere verilen geçiş izni, buz kırmaya yönelik ihtiyaçlar, kaynakların tükenme olasıllğı, hedef nakliye rotalarının henüz belirginleşmemesi, hava koşullarının uygun olduğu geçiş mevsiminin kısalı̆̆, tecrübe eksikliği, sigorta sisteminin tam/düzgün işlememesi, düşük yönlendirme/yol gösterme hızı, Arktika rotalarının hukuki statüsü, yetersiz izleme simülasyonu ve altyapı, yol göstermeye ilişkin veri eksikliği/düzensizliği, stok ve kar marjlarını etkileyen düşük devir hızı, hava koşullarının yol açtığı zayıf performans, rakiplere hızlı tepki gösterememe, sinerji eksikliği; firsatlar, sürekli küresel genişleme, Asya-Avrupa geçiş hız1, turistik talep artış1, Arktika deniz buzunun azalması, petrol ve doğalgaz arama, yeni çıarma/işleme teknolojileri, yeni balıkçılık alanları, yeni araştırma alanları, uluslararası organizasyonlar, önceki kutup taşımacıllı̆ı çalışmalarından/tecrübelerinden faydalanma, sağlık harcamaları artışı, deniz güvenlik sektörüne yönelik firsatlar; tehditler, yüksek emtia ve enerji fiyatları, döviz kurlarındaki dalgalanmalar, kuralsızlaşma durumunda çevresel kirlilik, çevresel düzenlemelere uyum sağlayamama, üretim düşüklüğü, kutup deniz trafiğinde artış, manyetik pusulada sapma, yerelde sosyal dönüşüm, bölgesel bilgi eksikliğinin yarattığı belirsizlik, buzullar dolayısıyla sigorta bedellerinde artıs, buzullarda erimeden kaynaklı kütlesel yer değiştirme, yerelde kutup hayatının sekteye uğraması (Şahin vd., 2014: 673-674; AMSA, 2009: 72-125; Kwok ve Armitage, 2017: 5-6). 
yaklaşımına yer verilirken, son kısım ise bölge politikalarına yönelik genel bir değerlendirmeden oluşmaktadir.

\section{Arktika'nın Ekonomik Önemi}

Arktika bölgesi, küreselleşme ve bölgesel entegrasyonların gelişip derinleşmesiyle birlikte; jeopolitik, jeostratejik, ekonomik, bilimsel araştırma, çevre koruma, deniz geçişleri ve doğal kaynaklar konularında önemini giderek arttırmaktadır. Öyle ki, son yıllarda küresel 1sınmanın etkisiyle buzulların erimesi ve kar örtüsünün incelmesi Arktika bölgesinin kutup ülkeleri ve bölge dişındaki devletlerin çıkarları yanında, bir bütün olarak uluslararası toplumun çıkarlarına ve ortak geleceğine hitap eden öneme sahip hale gelmesini sağlamıştır (The State Council, 2018: 1). Zira Kuzey'de gözlemlenen ve öngörülen yıllık ortalama 1sınma, kış aylarında hızlanarak küresel ortalamanın iki katından fazla artışıyla süregelmektedir. Örneğin 1971-2017 y1lları arasında Arktika y1llı yüzey havası sıcaklıkları, Kuzey Yarımküre ortalamasından 2,4 kat daha hızlı artmıştır. Karaya bağlı buzun azalması, daha sicak hava ve artan firtına, dalga ve gelgitlerin neden olduğu sudan dolayı, kıyı erozyonu oluşmaktadır. Diğer yandan deniz buzu, taşımacılık ve doğal kaynakların çıkarılması gibi ticari faaliyetlere engel teşkil ettiği için, deniz buzu kaybıyla yeni ekonomik faaliyetlerin ortaya çıkması beklenmektedir. Ancak unutulmamalıdır ki iklim değişikliği, çevre ve sağlık sorunları (örneğin, kirlilik, okyanus asitlenmesi, erozyon) ile bir dizi sosyal, ekonomik ve politik faktörle (göç, kaynak çıkarma, yerel kalkınma, rekreasyon, turizm) etkileşim halindedir ve bu unsurlar Kuzey'in doğasını değiştirmektedir (AMAP, 2019: 4-9). Yani bölgede değişen koşullar, ekonomik firsatlar ve zorlukları beraberinde getirirken, canlı kaynaklara dayanan geçimlik faaliyetlerin zarar görmesi daha olası görülmektedir. Örneğin hayvanlar ve bitkiler doğrudan yükselen sicaklıklardan, toprakların çözülmesinden, değişen kar ve buz koşullarından etkilenmekte ve ayrıca kriyoferik değişiklikler hasat faaliyetlerini zorlamaktadır.

Son dönemde hızla eriyen buzullar, Kuzey Avrupa ve Doğu Asya’y1 birbirine bağlayan $7.000 \mathrm{~km}$ civarında bir deniz yolu açmakta, bu yeni kuzey koridoru, yeterince erişilebilir olması halinde, Asya ve Avrupa arasında ticaret akışını sağlayan alternatif bir nakliye rotasını oluşturmaktadır. Yeni kuzey rotası "Arktika İpek Yolu" olarak da adlandırılmakta ve araştırmacılar tarafindan kıtalararası taşımacılıkta zaman ve maliyet açısından bir potansiyel olarak görülmektedir (Descamps, 2019: 1-2). Bunun yanı sıra, açık bir Kuzey Kutbu geçişi, Avrupa, Asya ve Kuzey Amerika'y1 birbirine bağlarken, özellikle Asya ticareti için birkaç önemli stratejik kilit noktasının atlanmasını sağlayacak alternatif bir arter sunmaktadır. Öyle ki Arktika Enstitüsü (The Arctic Institute-Washington merkezli bir düşünce kuruluşu) tarafindan yayınlanan 2014 raporuna göre, 2013 yilında 71 gemi Kuzey Denizi güzergâhı boyunca 1.35 milyon ton mal taşımıştır. Bu rakam 2012 yılında 46 
gemi ile 1.26 milyon ton olarak gerçekleşirken, bu gelişme bölgenin ticari gemiler tarafından her geçen gün daha fazla tercih edildiğini kanıtlamaktadır. Raporda, 2013 yllinda toplam 41 geminin (ki bunların 30’u kargo taşımaktadır) Kuzey Kutbu nakliye şeridini Asya'dan Avrupa yönünde kullandığını, trafiğin geri kalanının ise Kuzey Avrupa'dan Asya’ya tek yönlü fosil yakıt nakliyesi veya Rus limanları arasında gerçekleştiğini vurgulamaktadır (Deere-Jones, 2016: 5). Yakın zamandaki gelişmeler göstermektedir ki deniz buzunun erimesi Arktika'yı her yaz daha uzun sürelerle nakliyeye açarak, kutup ötesi ticari nakliye firsatlarını arttırmaktadır. Deniz taşımacıllı̆ında kullanılan yeni ve nispeten kısa yollar, enerji kullanımını ve sera gazı emisyonunu azaltırken, aynı zamanda ticareti de teşvik etmektedir. Uzmanlar, Kuzey Deniz Yolu'nu kullanan ticari gemilerin, Avrupa ve Pasifik arasındaki mevcut deniz taşımacıllğı güzergâhına göre \%40 daha kısa bir rotayı takip ettiğini vurgulamaktadır. Bu sayede de, söz konusu güzergah boyunca taşıma hacminin 2020 yllina kadar 12,8 milyon tona kadar artacağ tahmin edilmektedir. Deniz yolu taşımacıllŏı artış1 ile bölgedeki doğal kaynakların çıkarılması ve denizcilik turizmi gibi faaliyetlerden kutup bölgesi dişındaki şirketlerin de faydalanması beklenmektedir. Bir diğer ifadeyle bilim ve turizm amaçlı geziler başta olmak üzere Arktika, yaz dönemi gezileri için de firsatlar sunmaktadır. Bu noktada turizmin yerel topluluklara önemli düzeyde fayda sağlaması beklenirken, mevcut durumda bile artan turizmle Alaska'da her y1 39.000 kişi için iş imkânı sağlanmakta ve 1.15 milyar $\mathrm{ABD}$ Doları seviyesinde ücret ödenmektedir (AMAP, 2011: 77).

Deniz taşımacilığında kullanılacak yeni rotaların sağlayacağı maliyet tasarrufu yanı sıra, Arktika'daki iklim değişikliğinin diğer bir potansiyel avantaj1, enerjiye erişilebilirliktir. Bölgede henüz keşfedilmemiş petrol ve gaz yatakları, küresel açıdan gelecekteki enerji arzı ile ilgili en büyük belirsizliklerden biri ve aynı zamanda çevre ile ilgili büyük bir kayg1 unsurudur. ABD Jeolojik Araştırma Enstitüsü, dünyada keşfedilmemiş gazın \%30'unun ve keşfedilmemiş petrolün ise \%13'ünün Kuzey Kutup Dairesi'nde yer aldığını ve bunun da suyun 500 metre altında olduğunu tespit etmiştir. Araştırmalara göre bölgede keşfedilmemiş olan doğalgaz, petrolden üç kat daha fazladır ve bu Rusya'ya yakın bölgelerde yoğunlaşmaktadır (Gautier vd., 2009: 1175). Bir başka açıdan değerlendirildiğinde, Arktika bölgesinde yer almayan devletler, bölgesel bir egemenliğe sahip olmamakla birlikte, bilimsel araştırma, denizcilik, taşımacılık, bölgenin hava sahasını kullanma, balıkçılık, denizaltı kabloları ve boru hatlarının döşenmesi gibi konularda $\mathrm{UNCLOS}^{8}$ ve uluslararası hukuka tabi çok taraflı anlaşmalar uyarınca kaynak arama ve kullanma hakkına sahiptir. Buna ek olarak Spitsbergen Antlaşması'na taraf ülkeler de Kuzey'in

8 United Nations Convention on the Law of the Sea (Birleşmiş Milletler Deniz Hukuku Sözleşmesi). 
belirli alanlarında bilimsel araştırma, avcılık, balıkçılık, madencilik gibi ticari faaliyetler ve üretim yapabilirler (The State Council, 2018: 2). Bu çerçevede Şekil 1, yerel unsurlar ile uluslararası şirketlerin Arktika'da faaliyet gösterdiği endüstrileri özetlemektedir.

\section{Şekil 1. Arktika'nın Ekonomik Potansiyeli}

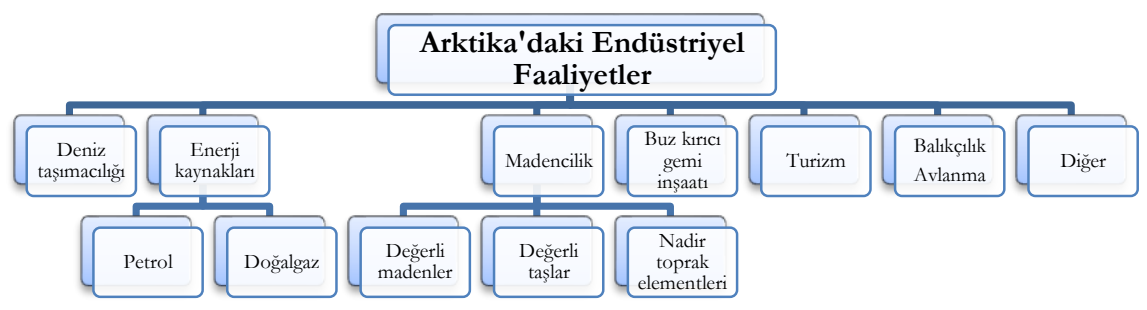

Bütün bunlar göz önüne alındığında, bu çalışmanın da odağını oluşturan Çin'in Arktika'ya yoğun bir şekilde yatırım yapması ve ilgisini arttırması şaşırtıcı değildir. Zira Pekin, Arktika ile ilgili birçok organizasyonda (Kutup Navigasyon ve Ekipman Komitesi gibi) üyelik kazanmaya çalışmakta, serbest ticaret anlaşmaları, madencilik, altyapı projeleri yatırım planlarına dâhil olmaya yönelik adımlar atmakta ve diğer egemen küresel güçler gibi Arktika ülkeleriyle diplomatik ilişkilerin geliştirilmesine yönelik faaliyetlerde bulunmaktadır. Bu bağlamda izleyen bölümde Çin'in Arktika politikaları irdelenecektir.

\section{2. Çin'in Arktika Politikası}

Çin hükümeti 2018 yllı Ocak ayında, Kuzey Kutbu ile ilgili temel pozisyonlarını ortaya koymak, Kuzey Kutbu ile ilişkilerine yönelik temel ilkelerini ve politika hedeflerini açıklamak, Arktika ile ilgili faaliyetlerde ve işbirliğinde Çin hükümetinin ilgili bölümlerine ve kurumlarına rehberlik etmek, ilgili tarafları Arktika yönetimine daha iyi katılmaları için teşvik etmek, bölgedeki barış, istikrar ve sürdürülebilir kalkınmayı sağlamak ve desteklemek için uluslararası toplumla birlikte çalışma hedeflerini açıkladığı "Çin'in Arktika Politikası" başlıklı bir rapor yayınlamıştır. Raporda Kuzey Kutup Dairesi'ne en yakın olan kıta devletlerinden biri olarak kendisini "Yakin Arktik Devlet" olarak niteleyen Çin, bölgenin önemli bir paydaş1 olduğunu özellikle vurgulamaktadır. Arktika'nın doğal koşullarının Çin'in iklim sistemi ve ekolojik çevresi ve buna bağlı olarak tarım, ormancılık, balıkçılık, denizcilik endüstrisi ve diğer sektörlerdeki ekonomik çıkarları üzerinde doğrudan bir etkisinin olduğuna da raporun ilgili bölümlerinde değinilmektedir (The State Council, 2018: 2).

Çin'in Arktika yönetim hedefi deniz seferi uygulamaları, çevrenin korunması, bilimsel araştırma ve kaynak araştırmalanı için keşifler gibi birçok konuyu kapsamaktadır. "Arktika Stratejisinin" başlatılmasıyla vurgulanan 
stratejik hedefler somut eyleme dönüştürülmeye çalısıllmaktadır. Çin, büyük ölçüde Fransız yatırımı olan Total ve Çin yatırımı olan Çin Ulusal Petrol Şirketi'ne bağlı olan Yamal LNG projesi gibi girişimler yoluyla Rusya ve diğer devletlerle bilimsel araştırma ve kaynaklara dayalı ortaklık temelinde işbirliği geliştirmektedir. Bu tür projeler Çin'e, daha ileri teknolojiye sahip Rusya'dan teknolojik kazanımlar elde etmesini sağlamaktadır. Pekin'in 2018'de Kutup işlerine ve işletmelerine katılma çabaları, ilk yerli olarak inşa edilen buz kırıcı geminin piyasaya sürülmesiyle sonuçlanmıştır (Descamps, 2019: 3). Buradan hareketle Çin'in Arktika'da bölgelerarası ve küresel meselelerle, özellikle iklim değişikliği, çevre, bilimsel araştırma, denizcilik rotalarının kullanımı, kaynak arama ve kullanma, güvenlik ve küresel yönetim gibi alanlarla yakından ilgilendiği kolaylıkla söylenebilir (The State Council, 2018: 3). Özellikle deniz yollarının kullanılması ve Arktika'daki kaynakların araştırılması ve geliştirilmesi, dünyanın en büyük ticaret ülkesi ve enerji tüketicisi olan Çin'in enerji stratejisi ve ekonomik gelişimi üzerinde büyük bir etkiye sahip olabilir.

Bu noktada Çin'in Arktika'ya duyduğu ilgi üç başlık altında incelenebilir: Birincisi, Pekin, buzulların azalması ile daha kolay yararlanılabilecek olan fosil yakttlar, mineraller ve metaller dahil hammaddelere erişmeye çalışmaktadır. Çin, eşik büyüme oranlarını sürdürmek için bu hammaddeleri geliştirmek istemesine rağmen, bu konudaki eylemlerinin ABD, Avrupa Birliği ve son yıllarda Arktika ekonomi politikalarını geliştiren Avustralya, Hindistan, Japonya ve Güney Kore'nin yer aldığı Asya Pasifik ülkeleri tarafından izlendiğinin farkındadır. Ayrıca Kuzey Kutup denizi rotalarının, özellikle Kuzey Sibirya kıyllarındaki Kuzeydoğu Geçidi'nin açılması, Avrupa'ya ve ötesine mal ihraç etmek isteyen Çin'e daha hızlı ve daha ucuz yollar kullanma imkânı sunmaktadır. Bu da Çin'in bölgeye ilgi duymasının ikinci nedenini oluşturmaktadır. Zira Çin diğer Asya ülkeleri gibi Kuzey Kutup deniz taşımacilığının avantajını elde etmek ve potansiyel ticaret yollarının geliştirilmesi ile bölgenin regülasyonunda kullanılacak yasal rejimler konusunda söz sahibi olmak istemektedir. Üçüncü ilgi odağı, Çin'in Arktika Konseyi'nde 2013 yllında resmi gözlemci statüsü elde etmesi ardından Konsey'de genişletilmiş rol alma isteğidir (Lanteigne, 2014: 9-10).

Her ne kadar Pekin'in zaman zaman ihracat vurgusundan uzaklaşarak, daha fazla yurt içi büyüme ve hanehalkı tüketimine yönelerek ekonomiyi dengeleme hedefi olsa da, Çin ekonomisi kısa vadede mal ihracatına bağlı kalacak ve bundan dolayı Çin ürünlerini Batılı pazarlara daha hızlı ve daha etkin ulaştıracak yollar politika yapıcıların dikkatini çekecektir. Ayrıca Çin ticaretinin büyük kısmı için Hint Okyanusu ve dar Malakka Boğazı'nı kullandığından, politik olarak daha az hassas bölgelerin kullanımı arayışındadır ki Arktika bu konuda önemli bir potansiyeli barındırmaktadır. Geçtiğimiz otuz yil boyunca Çin her ne kadar bölgesel güç olma hedefi ile Doğu Asya’ya daha fazla ilgi göstermiş olsa da, stratejik kaygıları nedeniyle 
ilgisini Doğu Asya’nın ötesinde Afrika, Latin Amerika ve kutup bölgelerine yöneltmektedir9. Denizaşırı kaynaklara duyduğu ihtiyaç, özellikle enerji kaynakları ile dış ticareti için güvenilir, düşük maliyetli ve uygun deniz yolları sağlama arzusuyla Çin, kutup çevresindeki ülkelerle enerji ile sinırlı kalmayacak şekilde kapsamlı ekonomik ilişkilere yönelmiş, yatırım teklifleri ve artan ikili ticareti ile bölge ile olan ilisskileri güçlendirmek istemektedir (Chen, 2012: 367).

Ayrıca Çin, küçük kutup topluluklarının yer aldığı kuzey bölgelerine yakın coğrafi konuma sahip bir ülkedir. Bunun yanı sira bu bölge üzerinde, askeri olarak güçlü, bilimsel ve ekonomik olarak ileri olan küresel devletlerin de hâkimiyet kurmak istediği bilinmektedir. ABD ve Rusya'nın da içerisinde bulunduğu bu güçlerle rekabet etme zorunluluğu ise Çin'in zengin kaynakları elde etme isteğini arttırmaktadır. Çin yakın geçmişte dünyanın en büyük ikinci ekonomisi olma statüsünü elde ederken, bazı tahminlere göre, gelecekte Amerika Birleşik Devletleri'nin yerini alarak birinci sıraya yükselmesi beklenmektedir (Kopra, 2013: 4). Bir başka ifadeyle Çin'in uluslararası statüsü hem ekonomik hem de politik açıdan çarpıcı biçimde ilerleme gösterirken, özellikle son on yllda, Çin’in bu yükselişinin dünya için bir tehdit mi yoksa bir firsat $\mathrm{m} 1$ olacağ konusunda fikir ayrllıkları bulunmaktadır.

Çin "bölgesel güç olma" hedefine, Asya Pasifik'e yönelerek ve Afrika, Avrupa, Latin Amerika ülkeleri ile dünyanın kuzey ucunda yer alan Arktik bölgesinde ilişkilerini güçlendirerek ulaşmaya çalışmaktadır. Uluslararası alanda özellikle ABD ile "büyük güç" stratejilerinin çarpışması ise dış ticaret politikalarının gözden geçirilmesini gerekli kılmıştır. Önceki dönemlerde büyük güç olmanın temel anahtarı olarak hızlı büyümenin gösterildiği Çin'de, değişen ve ele alınan yeni politikalar sayesinde artık kurallı ve düzenli büyüme anlayışına geçildiği görülmektedir. Her koşulda hızlı büyüyen büyük

\footnotetext{
${ }^{9}$ Bu noktada "Kuşak ve Yol Girişimi”’nden de bahsedilebilir ki bu Girişim, bölgesel işbirliği ile açık dünya ekonomisi ve küresel serbest ticaret rejimini tesis etmek ve korumak için tasarlanmıştır. Bunun yanı sıra söz konusu Girişim, ekonomik faktörlerin düzenli ve serbest dolaşımını, kaynakların etkin tahsisini ve piyasaların entegrasyonunu teşvik etmeyi amaçlamaktadır. Piyasaların entegrasyonu için Kuşak ve Yol Girişimi boyunca yer alan ülkelerin ekonomik politika koordinasyonunu sağlamak ve daha yüksek standartlarda daha derin bölgesel işbirliğini ortaklaşa oluşturmak, dünya topluluklarının lehine gelişecektir. $\mathrm{Bu}$ noktada Çin'in dünya ekonomisi ile yakından ilgilendiği de vurgulanabilir. Kuşak ve Yol Girişimi, Çin'in açılma politikalarını genişletmesini ve derinleştirmesini, Asya, Avrupa, Afrika ve dünyanın geri kalanı ile karşlıklı yarar sağlayan işbirliklerini güçlendirmesini mümkün kılacaktır. Asya, Avrupa ve Afrika kıtalarından geçen bu girişim, Doğu Asya ve Avrupa'yı birbirine bağlarken, İpek Yolu Ekonomik Kuşağı Çin’i Merkez Asya ve Batı Asya yoluyla Basra Körfezi ve Akdeniz'e, Güneydoğu Asya’ya, Güney Asya'ya ve Hint Okyanusu'na bağlayarak Çin, Merkez Asya, Rusya ve Avrupa'yı bir araya getirecektir. 21. Yüzyıl Deniz İpek Yolu ise, Güney Çin Denizi ve Hint Okyanusu ile Güney Çin Denizi ve Güney Pasifik üzerinden Çin sahilinden Avrupa'yı bağlamak üzere tasarlanmıştır (NDRC, 2015).
} 
ülke olma hedefi ile stratejisinin yerini, yıkıcı güç anlayışının terk edildiği, uluslararası piyasalarla dost bir ekonomi olma hedefi almıştır. Barışçıl kalkınma süreci olarak da adlandırılan bu atılım doğrultusunda Çin'in yeni pazarlara ulaşılabileceği düşünülmektedir. İkili ticari anlaşmalar, uluslararası kuruluşlara katılım, ekonomik işbirlikleri, iş ortaklıkları gibi ticaretin artışına katkı sunan hamleler, kalkınmada bölgesel lider olma stratejisinin bir parçası olarak görülmektedir (Lanteigne, 2014: 6 ). Bunun yanında özellikle bölgesel kaynakların keşfi için Çin'in Artktika'ya yönelik ilgisi, kaynakların çıkarılması konusunda avantajlar sağlamaktadır, ancak diğer ülkeler, Çin'in bu hızlı büyüme isteğinin çevresel dengenin aleyhine sonuçlar doğuracağına da inanmaktadırlar (Brady, 2017: 4-5). Çünkü çıkar çatışmalarının kendini gösterdiği Kuzey Kutbu ekonomisi; metalik mineraller, değerli metaller, hidrokarbonlar, kıymetli ve yarı kıymetli taşlar ve balık gibi nispeten dar bir kaynak tabanı ile karakterize edilmektedir. Bunların zenginlik yaratma potansiyelleri yadsinamazken, sermaye yoğunluğu yüksek bir üretim yapısına ihtiyaç duymaları, dış sermaye bağımlılığını da beraberinde getirmekte, çevreyi öteleyen sermaye yoğun bir üretim süreci ise ekosistemin bozulmasina neden olmaktadır (Larsen, 2010: 121). Bu durum kaynaklara erişim ve bunların kullanımında çevrenin sürdürülebilirliğinin de dikkate alınması gerekliliğini ortaya koymaktadır. Çinli yetkililer, ekonomik faaliyet bakımından çeşitlilik eksikliği ve doğal kaynağa bağlı büyüme hedefinden kaynaklanan Arktik bölgesinde yaşanan istikrarsızlıkların, çevreyi gözeten ve dış pazara ulaşabilme kabiliyetinin arttırılmasına yönelik politikalarla ortadan kaldırlabileceğine inanmaktadırlar (AHDR, 2004: 2-3).

Çin ile birlikte bölgeye ilgi duyan diğer devletlerin Arktika'daki faaliyetlerini her geçen gün arttırması bazı yeni endüstrilerin doğmasına ve ilerlemesine yol açsa da, bu durumun çevresel açıdan yansımaları da mevcuttur. Şekil 2'de de gösterilen bu çevresel etkilere yönelik politikaların, kurulan işbirlikleri aracıllğıyla bölgede uygulanması, sürdürülebilirlik için kaçınılmaz görünmektedir. Aksi takdirde birbirini besleyen bir döngünün oluşması kaçınılmaz görünmektedir. 


\section{Şekil 2. Arktika'daki Ekonomik Faaliyetlerin Çevresel Etkileri}

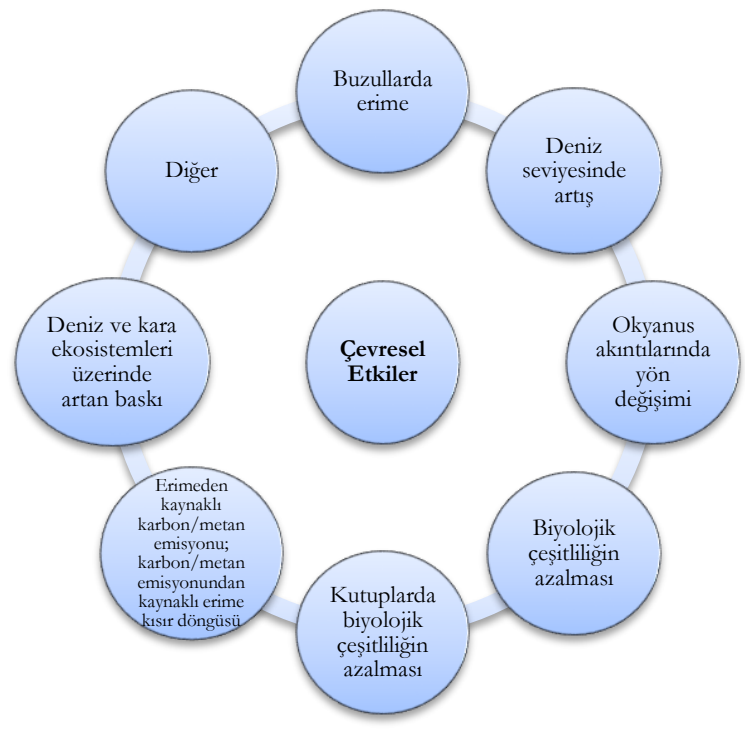

Bu noktada çevresel korumaya yönelik işbirliği tesis etmek başta olmak üzere, Arktika Konseyi'ne üye olan ya da olmayan gözlemci devletlerde, birbirlerinin haklarına saygı duyma temelinde, iletişimi güçlendirme, karşlıklı güveni arttırma, birbirine destek olma ve yakınsamaya açık alanlar yaratma konusunda bir anlayış gelişmektedir ki bölgesel kalkınmanın sürdürülebilirliği için bu işbirlikleri oldukça önemli görülmektedir (Hong, 2014: 284). Zira bölge ekonomisine bağlı olan yerel halklar başta olmak üzere tüm insanların yaşamlarını sürdürmesi için işbirliklerini gözeten bir kaynak dağıllımı sürecine de ihtiyaç bulunmaktadır. Ayrıca iklim değişikliği ve küresel üretim süreçlerinin ortaya çıkardığı zorlukların, Arktika ekonomilerinin sürdürülebilirlikleri için önemli sonuçları olan kaynakların tahsisi, kullanımı, mülkiyeti ve kontrolü kararlarında başlıca rol oynaması beklenmektedir. Çünkü artık Kuzey'de, arazi kullanımı ile yenilenebilir ve yenilenemeyen kaynakların dağılımına yönelik çok çetin bir rekabet ve bunu gözeten çıkarlar mevcuttur (Larsen, 2010: 204). Bu çıkarların, iklim değişikliği ile birlikte düşünüldügünde, bölgeye telafisi mümkün olmayan zararlar verebileceği unutulmamalıdır.

Görüldüğü üzere Arktika, Çin açısından çok yönlü önem arz etmektedir. Ancak bu çalışmada özellikle, küresel ısınmanın etkisiyle eriyen buzulların oluşturduğu koridordan hareketle deniz yolu taşımacillğına, enerji kaynaklarına ve Çin'in bölgeye yönelik yatırımlarına odaklanılmaktadır. Elbette bunların dişında bölgeye yönelik çok çeşitli analizlerin yapılması mümkündür ancak söz konusu analizler bu çalışmanın kapsamı dışında tutulmuştur. 


\subsection{Deniz Yolu Taşımacılığ}

Yerel ve bölgesel ekonomiler, küresel değişim süreçlerinin ve küresel pazarlarda meydana gelen değişimlerin etkilerini giderek daha fazla tecrübe etmektedirler (Larsen, 2010: 81). Dahas1, küresel 1sınma, gezegenin birçok yerindeki insanlar ve toplumlar üzerinde doğrudan etkisini deniz seviyeleri açısından da gösterecektir. Buzulların ve buz tabakalarının erimesi nedeniyle, ortalama deniz seviyesi yükselmeye devam edecektir ki tahminler 2100 yllında deniz seviyesinin 0,52-0,98 metre yükseleceğini göstermektedir. Ancak bu sonuçlar tabi ki gelecekteki sera gazı emisyon seviyelerine de bağlıdır. Ayrıca Hükümetler Arası İklim Paneli'nin (IPPC), 2013 yılındaki değişim değerlendirmesi, 1979'dan 2012'ye kadar olan dönemde deniz buzu miktarının son on yılda $\% 3,5$ ila $\% 4,1$ oranında azaldığını ifade etmektedir. Kayıtlar Arktika Okyanusu'ndaki buz kalınlı̆ının 1980 ile 2008 arasında ortalama 1,3-2,3 metre azaldığını göstermektedir (Loukacheva, 2015: 53). İklim değişikliğinin hızlı ilerleyişi ve deniz buzulunun erimesiyle birlikte birçok gözlemci, bölgeyi çevreleyen ülkeler için umut verici jeostratejik firsatların doğduğunu düşünmektedir. Bir başka ifadeyle bu sürecin, Kuzey Kutbu'ndan batıya doğru yeni bir ticaret rotası oluşturulmasının önünü açacağ1 tahmin edilmektedir. Zira bu yol ile Atlantik ve Pasifik arasındaki mesafe daha kısa olacak ve Süveyş veya Panama Kanalları üzerinden mevcut alternatiflere kıyasla ticaret akışı kolaylaşacaktır (Huang vd., 2015: 59). Buradan hareketle yakın gelecekte, enerji, madencilik, balıkçılık ve turizm sektörlerinde önemli ölçüde iş olanaklarının sağlanabileceği, Arktika denizcilik rotalarının, Süveyş Kanalı veya Panama Kanalı gibi geleneksel geçitlere kıyasla lojistik açıdan daha verimli rotalar olarak kullanılabileceği söylenebilir (Kopra, 2013: 1). Bu noktada hızlı buzul erimesinin nedeni olarak ise küresel karbon emisyonu gösterilmektedir ki Kuzey'in çoğu bölgesindeki sıcaklıklar son birkaç on yılda, (Özellikle kış sıcaklığı) Alaska ve Batı Kanada'da 3-4 ${ }^{\circ} \mathrm{C}$ artış göstermiştir. Gelecekteki senaryolar ise daha ürkütücüdür ve iklim modellerinde 2080 'de sicaklığın $3-6{ }^{\circ} \mathrm{C}$ daha fazla olacağını vurgulanmaktadır (Loukacheva, 2015: 52).

Arktika buzu aşınmaya devam ettikçe, ticaret yollarındaki uluslararası tartışma üç potansiyel suyoluna odaklanmıştır; Kuzeydoğu Geçidi, Kuzeybatı Geçidi ve Kutup Ötesi Geçidi (Merkezi Arktika Rotası). Bering Boğazı'ndan Sibirya'nın kuzey kıyılarına paralel uzanan Kuzeydoğu Geçidi Kuzey Avrupa'yı Kuzeydoğu Asya'ya bağlar ve sadece Çin için değil, Japonya, Singapur ve Güney Kore gibi birçok Asya ülkesi için Avrupa pazarlarına ulaşmanın pratik yolu olarak görülmektedir. Kuzeybatı Geçidi, Kanada'daki Arktika Okyanusu adaları ve Kuzey Kanada'daki Nunavut'tan geçmektedir. Kanada Arktika Takımadaları'ndaki çok sayıda ada ve dar boğazlar, bu rotaları gemiler için doğu geçidinden daha karmaşı hale getirmektedir. Uluslararası taşımacılıkta zaman ve maliyet açısından daha fazla tasarruf sağlayacak olan Kuzey Ötesi Geçidi ise diğer iki geçide göre 
daha hipotetik olmakla birlikte, buzulların hızla erimesi sonucu 2040 yll yazında Arktika'nın buzulsuz kalacağı beklentisi, Panama, Süveyş Kanalları ve Malakka Boğazları gibi geleneksel suyollarını transit kullanan gemilerin alternatif olarak kuzey deniz yolunu kullanma olasıllklarını gündeme getirmektedir. Bu noktada 2013 yllinda Danimarkalı bir firmanin sahip olduğu kargo gemisinin Kuzeybatı Geçidi'ni başarıyla geçen ilk gemi olduğu da söylenebilir. Geleneksel Panama Kanalı geçidini atlayarak gerçekleştirilen rotalama, yedi seyahat günü ve yaklaşık $80.000 \mathrm{ABD}$ doları tutarında yakıt maliyeti tasarrufu sağlamaktadır (Lanteigne, 2014: 26-28). Geleneksel geçitlerin de içerisinde bulunduğu rotaların kullanımının zamanla azalması ve uluslararası taşımacılık yapan büyük firmaların Arktika'ya yönelmeleri elbette ki bu şirketlerin yakıt ve sigorta maliyetlerine olumlu yansiyacaktır. Ancak geleneksel rotalarda iktisadi faaliyetlerin azalmas1, bu rotada yer alan limanlardaki ve hatta şehirlerdeki istihdam ile geliri olumsuz etkileyecektir. Bir başka ifadeyle yeni Kuzey geçitleri, Panama ve Süveyş Kanalları ile Malakka Boğazı'ndaki ticareti kendi lehine değiştirecek ve bu durum söz konusu bölgelerde yaşayan bireylerin uzun vadede belki de göç etmek zorunda kalmalarıly sonuçlanacaktır.

\section{Şekil 3. Arktika'da Deniz Yolu Taşımacılı̆̆ı Rotaları ${ }^{10}$}

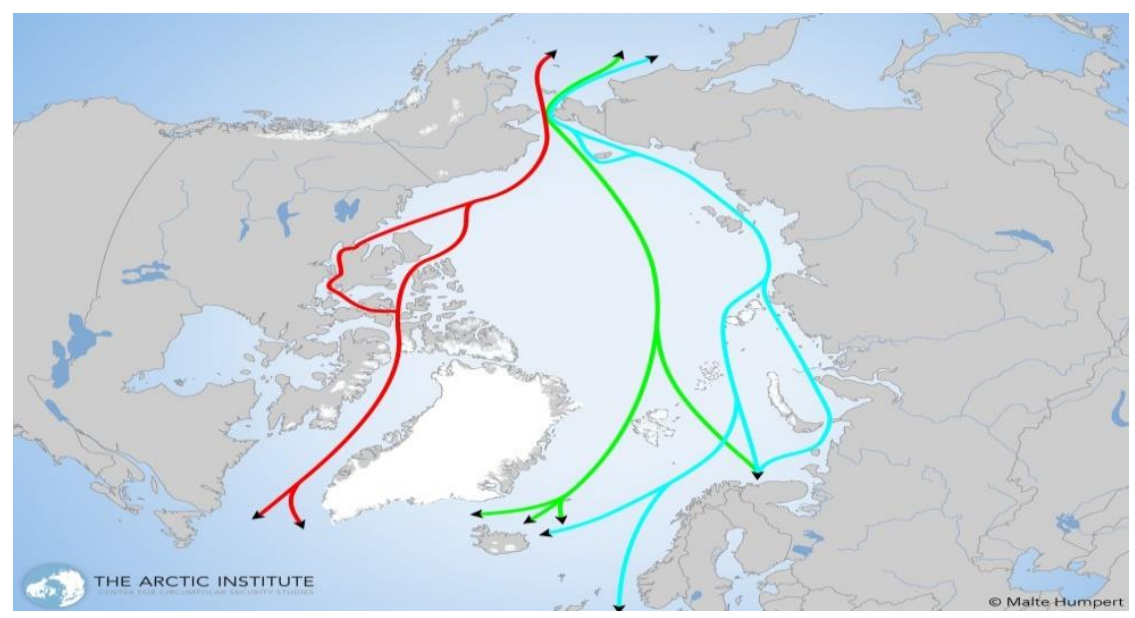

Kaynak: The Arctic Institute, 2019, https://www.thearcticinstitute.org/arcticmaps/

Tahminler Arktika Okyanusu'nun 2040 yllına kadar yaz mevsiminde sürekli olarak buzsuz kalacağını göstermektedir ${ }^{11}$ (IPCC, 2019). Bu durum,

\footnotetext{
${ }^{10}$ Kırmızı: Kuzeydoğu Geçidi; Mavi: Kuzeybatı Geçidi: Yeşil: Kutup Ötesi Geçidi (Merkezi Arktika Rotas1).

${ }^{11}$ Hatta 2100 yllında sıcaklığın $1,5^{\circ} \mathrm{C}$ ile $2{ }^{\circ} \mathrm{C}$ arasında değişmesinin, deniz suyu seviyesinde $10 \mathrm{~cm}$ 'lik bir farkllığa neden olması beklenmektedir. (IPCC, 2019). Bir başka ifadeyle sadece $0,5^{\circ} \mathrm{C}$ lik fark bile deniz seviyesini önemli ölçüde etkileyecektir.
} 
Asya ile Avrupa ve Asya ile Kuzey Amerika arasinda yeni ticari nakliye rotaları sunacaktır. Herhangi bir Kuzey Çin limanından Avrupa ve Kuzey Amerika'nın doğu kıyısı limanlarına giden yeni deniz taşımacılığı için elverişli bu Kuzey Kutup Denizi rotaları, geleneksel taşıma rotalarına kıyasla \%40 daha kısa olacaktır. Kuzey doğu güzergâhı ile Şangay'dan Hamburg’a ulaşımın, Malakka Boğazı ve Süveyş Kanalı rotasına göre 6.400 km daha kısa olacağ1 tahmin edilmektedir ki bu, yaklaşık 15 gün daha kısa yolculuğa karşılık gelmektedir. Arktik Okyanusu üzerinden kullanılacak kısa yolların maliyet etkinliğinin yanı sıra, Çin'in Malakka Yarımadası ile Endonezya Sumatra Adası arasındaki en yoğun deniz yollarından biri olan Malakka Boğazı'nı yoğun kullanımına ilişkin güvenlik önlemi de dikkate alınmalıdır. Doğu Afrika'da sık görülen korsan tacizlerinin Süveyş Kanalı ve Aden Körfezi'ni kullanan gemilerin sigorta primlerini arttırması, Çin'in muazzam dış ticareti için deniz yollarını çeşitlendirme konusundaki kararlılığını daha da pekiştirmektedir (Chen, 2012: 361).

Çin Polar Araştırma Enstitüsü Genel Müdürü Huigen Yang, Çin'in uluslararas1 ticaretinin 2020'de \%5-15'inin Arktika denizcilik rotas1 kullanılarak gerçekleşeceğini tahmin ettiklerini vurgulamışıtır (Kopra, 2013). Örneğin Hamburg-Yokohama yolculuğu için Süveyş Kanalı güzergâhından daha kısa mesafeden oluşan bu rotanın toplamı 4.800 mil $(7.700 \mathrm{~km})$ uzunluğundadır. Ayrıca Avrupa-Asya Kuzeybatı Geçidi (9.000 km), Panama Kanalı güzergâhından 100.000 mil (17.000 km) daha kısadır (Chircop, 2011). Eylül 2010'da Hong Kong bandralı MV Nordic Barents (buz sınıfı 1A) isimli bir demir cevheri yüklü kargo gemisi Norveç'ten Arktika rotasını kullanarak Şanghay'a ulaşmak için yola çıkarken, bu rotanın geleneksel olan rotaya göre $\% 40$ daha kısa olduğu görülmüş ve bu süreç, zaman ve yakıt tasarrufunun yanı sıra, karbon emisyonunun da düşürülmesiyle sonuçlanmışıtır. Bir başka ifadeyle Arktika rotası, söz konusu şirkete yaklaşı 180.000 ABD dolar1 değerinde yakıt tasarrufu sağlamıştır. Bu noktada şu da belirtilmeli ki transit geçişler için sunulan hizmetler (buzullar için rehberlik, kırım vb.) bir maliyet unsuru olarak şirketlerin karşısına çıkarken, sigorta ücretleri de bir diğer maliyet kalemi olmaktadır. Ancak diğer uzun rota taşımacılığında da söz konusu maliyetlerle karşı karşıya kalındığ1 düşünüldüğünde, yeni rotada maliyetlerin de nispeten düşük olduğu söylenebilir (Chircop, 2011: 14).

Arktika'nın Çin için öncelikli olma nedenlerinden birisi de, kendisinin güçlenmesi kadar, rekabet içinde olduğu ülkelerin hızını kesmek istemesinden kaynaklanmaktadır. Değinildiği üzere Batı Asya ve Avrupa için bir koridor olacak bu bölge, piyasalara daha ucuza ve kısa zamanda ulaşmanın anahtarı olarak görülmektedir. Zira İpek Yolu Ekonomik Kuşağı'nı, Deniz İpek Yolu'na dönüştürme planları Arktika geçişini daha da 
önemli kılmaktadır. Bir başka ifadeyle Arktika İpek Yolu ${ }^{12}$ olarak da adlandırılan bu kuşağın, Çin'in hem güvenliği hem de ekonomisi açısından büyük önem arz ettiği düşünülmektedir (Ping ve Lanteigne, 2015: 11).

Değinildiği üzere Pekin'e, yllarca süren müzakerelerin ardından 2013’te, Hindistan, Japonya, Singapur ve Güney Kore'nin de dâhil olduğu diğer Asya ülkeleri ile birlikte Arktika Konseyi’ne gözlemci üye statüsü verilmiştir. Ancak diğer üye olmayan devletlerle karşılaştırıldı̆̆ında Pekin, Arktika çıarlarını göz ardı ettiği için çok daha fazla uluslararası incelemeye ve eleştiriye maruz kalmışır. Bu durum ise özellikle ABD ile karşılıklı çıkar çatışmasına dönüşürken, zaman zaman ilişkilerin gerilmesine de neden olmuştur. Özellikle deniz yolu taşımacıllğında rekabet konusunda karşı karşıya kalındığı düşünüldüğünde, bu gerilimin gerçek nedeninin pazar payını elinde tutma olduğu anlaşılmaktadır. Bunun yanında Vietnam'ın tüm itirazlarına rağmen, Çin'in deniz yolunda inşa ettiği petrol kuyuları, güvenlik konusunda endişelere yol açmıştır (Ping ve Lanteigne, 2015: 8). Bu noktada Çin'in lojistik açıdan koridoru kullanma isteği, Arktika'nın yönetişimine katılmasını ve ikili diplomasiyi geliştirmesini zorunlu kılmaktadır. Potansiyel kaynaklarda söz sahibi olabilmenin ve kalıcı bir koridor niteliği kazanacak bölgenin, Batı'ya ulaşmak için bir fırsat olduğu açıtır. Ancak Çin Arktika Konseyi'nde kalıcı gözlemci olmasına karşın, Birleşmiş Milletler'in Deniz Hukuku Sözleşmesinin kısıtlamaları, Çin'in bölgedeki teknolojik altyapısını etkilemektedir. Bunun yanı sıra deniz taşımacılığının ve kaynak geliştirmenin küresel ısınmaya yansıyan olumsuz etkisi çevresel bozulmayı hızlandıırken, bu durum başta Çin olmak üzere bölgeye ilgi duyan ülkelerin eleştirilmesine yol açmaktadır (Hong, 2014). Bu nedenledir ki Arktika Konseyi ve bölgeye yönelik tüm işbirlikleri, çevrenin korunmasına ve bilimsel araştırmaların sayısının artırılmasına son dönemlerde daha çok odaklanmaktadır. Zira yeni Kuzey geçitleri, geleneksel rotalarda ticaretin azalmasıyla o bölgelerdeki sera gazı emisyonun gerilemesine yol açarken, büyük gemilerin Arktika'yı her geçen gün daha fazla tercih etmeleri, söz konusu emisyonun kuzeye transferiyle sonuçlanmaktadır. Her ne kadar kuzey rotalarının mesafe olarak daha kısa olması küresel kirliliğin azalması yönünde bir beklentiye yol açsa da, Arktika'daki artan sera gazı emisyonu buzulların erime hızını arttırmakta ve çevreyi olumsuz etkilemektedir Buradan hareketle Arktika geçitleri çevrenin hem lehine hem de aleyhine gelişen bir süreç yaratmaktadır. Bu nedenledir ki Konsey başta olmak üzere bölgeyle ilişkisi olan işbirlikleri, Çin'in de dahil olduğu tüm bölge ekonomilerinin Arktika'ya yönelik politikalarının topyekûn gözden geçirilmesini önermektedir.

${ }^{12}$ Literatürde Arktika İpek. Yolu, Buг İpek Yolu, Kutup İpek Yolu kullanımlar1 mevcuttur, ancak bu çalışmada Arktika İpek Yolu kullanımı tercih edilmiştir. 


\subsection{Enerji Kaynakları ve Değerli Madenler}

Çin 1978'den bu yana, hızlı ekonomik büyümeyi mümkün kılan ve uluslararası statüsünü önemli ölçüde arttıran bir dizi ekonomik ve politik reformdan geçmiştir. Gelinen aşamada dünyanın en büyük ikinci ekonomisi olarak gösterilirken, 20 yıl içinde dünyanın en büyük ekonomisi ve en kalabalık ülkesi olacağ1 da tahmin edilmektedir (World Bank, 2019). Ancak ekonomik reformlar 1970'lerin sonlarında başladıktan sonra, Çin ekonomisi enerji, üretim, inşaat ve altyapı geliştirme için hammadde ithalatına giderek daha fazla bağımlı hale gelmiştir. Bu nedenle Çin'in Arktika'da maden arama faaliyetlerini hızlandırması ve potansiyel petrol pazarını Orta Doğu'dan Arktika'ya çekme çabaları olağan görülebilir.

Günümüzde Arktika ve çevresinde 90 milyar varil petrol, 1.669 trilyon metreküp doğalgaz, 44 milyar varil sıv1 doğalgaz yer aldığı tahmin edilmektedir (Loukacheva, 2015: 32). Ayrıca şu anda dünyanın keşfedilmemiş doğal gaz rezervinin yaklaşı1k \%30 ve petrol rezervinin \%13'ünün bölgede olduğu tahmini yapılan araştırmalarla desteklenmektedir (Gautier vd., 2009: 1175). Bu noktada dünyanın en önemli petrol ithalatçıları arasında yer alan Çin'in, aynı zamanda en büyük bakır ithalatçısı ve ikinci hidrokarbon ithalatçısı olarak, dünyanın en büyük demir cevherine sahip Arktika'ya ilgi duyması kaçınılmazdır (Chircop, 2011: 12). ABD Enerji Bilgi İdaresi tarafindan yayınlanan raporlarda, dünya enerji tüketiminin 2008'den 2035'e kadar \%53 oranında artacağ1 öngörülmektedir (EIA, 2019). Artan küresel enerji talebinin temel itici güçleri ise Asya'nın hızla büyüyen ekonomileri olacaktır. Çin ve Hindistan başlıca petrol ithalatçısı ülkeler ${ }^{13}$ olarak ortaya çıkarken, 2035 yllına gelindiğinde, bu iki ülkenin enerji kullanımının toplam dünya enerji tüketiminin \%31'ini oluşturacağ1 tahmin edilmektedir. Bu noktada Arktika'daki rezervlere başarll bir şekilde erişilmesinin, küresel petrol ve gaz piyasaları üzerindeki baskının hafifletilmesine ve potansiyel olarak enerji güvenliğinin arttırlmasına yardımcı olması beklenmektedir (Hong, 2014: 271). ABD Jeolojik Araştırma Birimi’ne göre, Arktika kıta sahanlığı, dünyada kalan petrol için coğrafi olarak en büyük keşfedilmemiş potansiyeli bünyesinde barındırmaktadır (USGS, 2008: 1). Ayrıca Qingdao'daki Çin Okyanus Üniversitesi'nden denizbilimi uzmanı Profesör Li Sanzhong'un belirttiği gibi, Arktika bölgesinin önemli bir alanı yasal olarak henüz hiçbir ülke tarafından talep edilmemiştir. Araştırmacıya göre, Çin bu kaynakları araştırmak ve madencilik yapmak için gerekli bilgi/birikim ile yeteneğe sahiptir. Ancak her ne kadar

\footnotetext{
${ }^{13}$ Küresel ölçekte 2018 yllında en fazla petrol ithal eden ülke Çin olmuştur ki ele alınan yılda bu ithalat 239.2 milyar ABD doları seviyesine ulaşmıştır. Ayrıca Çin'in 2018 yllı petrol ithalatı, küresel petrol ithalatının \%20'sine karşlık gelmektedir. Dünyada Çin ve ABD'nin ardından en fazla petrol ithal eden 3. Ülke Hindistan'dır. Bu ülkenin 2018 yilı ham petrol ithalatı 114.5 milyar dolar iken, bu tutar toplamın \%9.7'ini oluşturmaktadır (WTEx, 2019).
} 
bilgi birikimi yeterli olsa da, petrol veya doğalgaz çıkarmak için gereken teknolojiye sahip olmadığ 1 için, çokuluslu petrol şirketleri ve Arktika ülkeleriyle enerji işbirliğine ihtiyaç duymaktadır. Örneğin Çin'in Rusya ile hâlihazırda geniş bir enerji bağı bulunmaktadır ve iki ülke gelecekte enerji işbirliğini ilerletme kararı almıştır (Xinhua, 2013). Ayrıca Çin'in Kanada'yla birlikte büyük yatırım yaptı̆̆1 katran kumları petrol üretme konusunda da planları bulunmaktadır (Kopra, 2013: 8).

Arktika'da buz tabakasının erimesi, petrol ve doğalgaz dışında bakır, altın, demir, nikel, platin, titanyum ve çinko gibi değerli metallerin, minerallerin ve elmas ve yakut gibi değerli taşların çıkarılması imkanını da yaratmaktadır. Ayrıca bölgede daha verimli enerji kullanımı için tasarlanan "yeşil teknoloji” dahil olmak üzere ileri teknoloji ürünlerin geliştirilmesinde gerekli olan "nadir toprak elementleri" de mevcuttur. Araştırmalar göstermektedir ki dünya çapında nadir toprak elementlerinin \%90'ından fazlası Çin'de çıarılmaktadır ${ }^{14}$ ve Çin'in bu tekel gücü, nadir toprak elementlerinin ileri teknolojiler geliştirme ve üretmedeki artan önemi nedeni ile Batı'da güvenlik endişesi yaratmaktadır.

Ekonomik büyümeyi teşvik etmek için Çin'in ithal etmesi gereken petrol ve doğalgaz her yıl artarken, Pekin, Arktika'daki fosil yakıt geliştirme potansiyeline büyük ilgi göstermeye başlamıştır. Petrol ve doğalgazın yanı sıra diğer fosil yakıtlar ve değerli metallerin çıkarılmasında kullanılacak bölgenin, "Yeni Ortadoğu" olabileceği ve Çin için "yeni bir yaşam çizgisi" yaratabileceği öne sürülmektedir. Gelinen noktada önemli bir enerji tedarik üssü olarak Pekin’in, bölgede enerji üreten ülkelerle geliştireceği ortaklılar ise büyük önem arz etmektedir (Lanteigne, 2014: 17-21).

Çin özelinde Arktika'nın doğal kaynak geliştirme potansiyeli çok büyük olsa da, kurulum ve tesis işletme maliyeti, çevresel zararın maliyeti, iklim değişikliğine bağlı olarak artan maliyetler gibi birtakım sorunlarla da karşı karşıya kalınmaktadır. Çünkü bu bölge, ekonomik kalkınma için gerekli olan büyük ölçekli kaynak çıkarma faaliyetleriyle ilgili çeşitli zorlukları da bünyesinde barındırmaktadır. Bu zorluklara, soğuk ve deniz buzu, uzaklık ve erişilebilirlik, Kuzey'deki yüksek üretim maliyeti, büyük ölçekli endüstriyel projeler için insan kaynağının kullanılabilirliği, hassas ekosistem, çevresel

\footnotetext{
${ }^{14}$ Çin dünyadaki en büyük nadir toprak elementi tedarikçisidir. 2011'den bu yana, çevresel bozulmayı azaltmak ve iç tüketim için kaynakları korumak için nadir toprak maden ihracatına kota koymuş, bu nedenle de söz konusu madenlerin küresel fiyatları hızla artmıştır. Bununla birlikte Çin'in tekel konumunu pekiştirmek için Çinli şirketler Grönland'ın nadir toprak yataklarıyla ilgilenmeye başlamışır. Örneğin, Çinli bir şirket yakın zamanda Grönland'da demir cevheri maden ocağı kurarak Grönland'daki en büyük endüstriyel proje gerçekleştirmiştir. Bölgede yllda 15 milyon ton demir cevheri üretilerek böylece gemilere yeni bir rota açılmıştır. Bu amaçla 1 milyar ton demir cevheri rezervi çıkartan maden inşa etmek için 2,3 milyar ABD doları yatırım yapılmış ve bu para Çin tarafından finanse edilmiştir (UTIKAD, 2019; Kopra, 2013: 8).
} 
etkilerin sonuçları ve yerli toplulukların kültürel ve geleneksel açıdan olumsuz etkilenmesi dahil edilebilir. Kuzey ekonomisinin büyük bölümünde, üretim maliyetlerinin yüksek olması ve geniş bir kaynak yelpazesinin bulunmaması, ekonomik çeşitliliği halen sınırlı tutmaktadır. Örneğin Kuzey'in bazı bölgelerinde yenilenemeyen ve en değerli kaynaklar arasında yer alan petrolün Arktik Okyanusu'ndaki rezervlerini karada ve kıyı hattında arama/çıkarma maliyetlerinin yüksekliği, üretim faaliyetlerini sınırlamaktadır. Değinildiği üzere Çin başta olmak üzere, birçok çevre ülke Kuzey Kutup bölgesinin ham minerallerle donatılmış olduğunun farkındadır ki Rusya rezerv bakımından bu konuda en büyük paya sahiptir. Mineral çeşitleri arasında kömür, demir cevheri, nikel, kobalt, kromit, titanyum, tungsten, boksit, çinko, kurşun, bakır, paladyum, altın, gümüş, platin, elmas, fosfat ve vermikülit bulunmaktadır. Finansal kaynak eksikliğinin yanı sıra endüstrinin sermaye yoğun niteliği nedeni ile endüstrinin mülkiyeti ve kontrolü az sayıda çok uluslu şirket tarafindan gerçekleştirilmektedir. Bununla birlikte, keşif ve başlangıç aşaması önemli ölçüde nitelikli emek girdisi gerektiren petrol ve türevleri, kaynak geliştirme sürecinde nihai olarak azalan emek talebi ve azalan çıktı ile de karakterize edilmektedir. Arktika'daki endüstriyel kaynak çıkarma faaliyetlerinin, gözlenen ve beklenen fiziksel, çevresel ve beşeri maliyetlere rağmen, artan küresel talep ve dünya pazarlarında istikrarlı ve güvenli kaynak arzına yönelik artan ihtiyaç nedeniyle genişlemeye devam edeceği öngörülebilir. (Larsen, 2010: 84).

Petrol ve türevleri ile değerli madenlerin çıkartılması konusunda gelinen noktada çevresel sorumluluk dili küresel ortak payda olarak kendini göstermektedir. Günümüzde Arktika’yı hayati öneme sahip bir bölge olarak kabul eden Çin, uluslararası toplumun iklim değişikliği konusunda harekete geçirilmesi çağrılarına olumlu cevap vermektedir ki bu bölge ve dünya için umut verici bir gelişmedir.

\subsection{Yatırımlar}

Çin hükümetinin ekonomik kalkınmayı tüm politikalarda temel öncelik olarak kabul etmesinden dolayı, Çin'in Arktika faaliyetleri hiç şüphesiz ekonomik itici güçler tarafından desteklenmektedir. Çünkü hızlı ekonomik büyüme Çin'de büyük enerji talebine neden olurken, bu durum petrol ihtiyacının karşılanması için yeni fırsatları da beraberinde getirmektedir (Kopra, 2013: 1). Kuzey'de, büyük şirketlerin artan varlığ1 ise kısmen sermayenin yüksek getiriye ve yüksek güvenliğe sahip ülke ve bölgelere yönelmesi gerçeği ile açıklanabilir. Büyüklükleri ve maliyetleri göz önüne alındığında, özellikle çokuluslu şirketlerin büyük ölçüde kaynak geliştirme projelerini finanse etme, tasarlama, inşa etme ve yürütme kapasitesine sahip olduğu söylenebilir. Ayrıca bu şirketlerin teknolojik bilgi, beceri ve modern makine/teçhizatını, öncelikle sermaye yoksunu bölgelere transferine katkıda bulunduğu da görülmektedir. Ancak, büyük şirketler yerel girişimciliği 
rekabet açısından dışlamasının yanında, küçük ölçekli yerel işletmelerin gelişimini de engelleyebilmektedir. Buradaki temel zorluk ise diş pazarlara olan bağımlılık ve bunun yol açtığ ekonomik istikrarsızlıktır. Daha önce belirtildiği gibi, Kuzey'deki doğal kaynak çıkarımının çoğu dış pazarlara yöneliktir (Larsen, 2010: 91). Bu nedenle yereli dışlamayan bir üretim modeli ve bölge işgücünü de kapsayan istihdam politikalarına ihtiyaç üst seviyededir.

Çin, son dönemlerde bölgeye yönelik yatırımlarını öncelikle nakit sıkıntısı çeken Grönland ve İzlanda'ya yönlendirirken ${ }^{15}$, Arktika devletlerinin bölgedeki kontrolünü zaylflatan ve Arktika İpek Yolu ile bölgede büyük oyuncu olma çabalarını destekleyen çok taraflı bir yönetişim geliştirmektedir. Deniz yollarının kullanılması ve Kuzey Kutbu'ndaki kaynakların araştırılması ve geliştirilmesinin, Çin'in enerji stratejisi ve ekonomik gelişimi üzerinde büyük bir etkiye sahip olması beklenmektedir. Çin bu hedeflere ulaşmak için Arktika bölgesi ticareti ve yatırımlarını kullanarak ekonomik kaldıraç gücü elde etmeyi planlamaktadır (Auerswald, 2019: 2).

Yakın dönemde Çin'in Arktika Bölgesi ülkelerindeki yatırımlarına bakıldığında hızla artış ivmesi göze çarpmaktadır ki söz konusu yatırımların neredeyse tamamı enerji, madencilik ve altyapı sektörlerine yapılmıştır (Rosen ve Thuringer, 2017: 57). Bu noktada Tablo 1, 2012-2017 döneminde Çin'in bazı Arktika ülkelerindeki doğrudan yatırımlarını yansıtmaktadır.

Tablo 1. 2012-2017 Döneminde Çin'in Arktika Kıyısı Ülkelerine Doğrudan Yatırımları

\begin{tabular}{lrrr}
\hline Hedef Ülke & $\begin{array}{r}\text { Hedef ülkenin } \\
\text { gayri safi yurtiçi } \\
\text { hasıla yüzdesi } \\
\text { olarak Çin yatırımı }\end{array}$ & $\begin{array}{r}\text { Çin yatırımının } \\
\text { toplam değeri } \\
\text { (milyar ABD doları) }\end{array}$ & $\begin{array}{r}\text { Proje başına } \\
\text { ortalama yatırım } \\
\text { büyüklügü (milyon } \\
\text { ABD doları) }\end{array}$ \\
\hline Grönland & 11.6 & 2 & 33.4 \\
\hline İlanda & 5.7 & 1.2 & 30.8 \\
\hline Rusya & 2.8 & 194.4 & 691.7 \\
\hline Kanada & 2.4 & 47.3 & 442.1 \\
\hline ABD & 1.2 & 189.7 & 340.6 \\
\hline Norveç & 0.9 & 2.5 & 147.9 \\
\hline
\end{tabular}

Kaynak: Rosen ve Thuringer, 2017: 54.

Çin'in tablodaki ülkeler arasında nüfusu ve ekonomisi itibariyle en küçük ülke olan Grönland'a yatırımı 2 milyar ABD Doları olmasına rağmen, ülkenin gayri safi yurt içi hasılasının \%11.6'sını temsil eden bu yatırımın Grönland ekonomisi üzerinde önemli etki yaratması beklenmektedir. Aynı dönemde ABD'ye yatırımı Grönland'e kıyasla oldukça yüksek olmakla birlikte, ABD ekonomisinin büyüklügü dikkate alındığında Çin yatırımlarının etkisi oldukça minimal olacaktır.

15 Özellikle demir rezervi çıkarma ve işleme yatırımı. 
Çin'in 2012-2017 döneminde en fazla yatırım yaptığ ülke Rusya olurken, proje başına ortalama yatırım büyüklüğü 691.7 milyon ABD Doları olan yatırımların toplam değeri 194.4 milyar ABD Doları olarak gerçekleşmiş ve Rusya'nın yılllk gayri safi yurt içi hasılasının \%2.8'ine tekabül etmişsir. Çin'in Kanada'daki yatırımları 47.3 milyar ABD Doları değeri ile Rusya ve ABD yatırımlarından daha düşük gerçekleşmiş olmakla birlikte, Kanada'daki ortalama yatırım büyüklüğü oldukça yüksektir. Bunun yanında İzlanda'ya gerçekleştirilen 1.2 milyar ABD Dolarlık yatırım ise İzlanda gayri safi yurt içi hasılasının \%5.7'sini oluşturmaktadır.

Çin, Ulusal Sosyal Bilimler fonuna ek olarak, Antarktika ve Arktika'da yllık yaklaşık 15 milyon dolar harcamaktadır. Temel savunma ve Çin'deki Polar Araştırma Enstitüsü ile Çin Arktika ve Antarktika İdaresi'nin (CAAA) işletilmesi maliyeti ise, yıllık kutup harcamalarını yaklaşık 60 milyon dolara getirmektedir. Bunun yanında yıllik kutup operasyonlarının yaklaşık \%20'si Arktika'ya tahsis edilirken, geri kalanı Çin'in 5 araştırma üssünün bulunduğu Antarktika'ya gitmektedir. Buradan hareketle, Arktika bütçesinin, Çin'in güney kutup bütçesine kıyasla çok az olduğu söylenebilir. Çinli yetkililer bu durumu "öncelikler" ile açıklamakta ve Antarktika'nın kendileri için daha büyük önem taşıdığını ifade etmektedir. Ayrıca Rusya'nın Kuzey Kutbu'na nükleer bir denizaltı yerleştirmeye ve 2007 yıllında deniz dibine Rus bayrağ1 yerleştirmeye karar vermesinin ardından, Çin'in Artrika'ya yönelik jeopolitik ilgisi daha da artmıştır. Rusya'nın atmış olduğu bu adımdan sonra, Çin hükümeti, ilave insan gücü desteği de dahil olmak üzere kutup araştırmalarına ayrılan kaynakları ve yatırımları artırmıstır (Tonami, 2014). Görüldüğü üzere Çin bölgenin bugünkü ve gelecekteki politikalarında söz sahibi olmak istemekte ve bunun için de bilimsel işbirliğine açık olduğunu çeşitli platformlarda ifade etmektedir. İşbirliğine yönelik atılması önerilen adımlar; ortak çalışma projeleri yürütmek, bölgeye yönelik araştırma ağlarını geliştirmek, düzenli atölye çalışmalarının toplanmasını sağlamak ve Çin ile Batı ülkeleri arası bilgi paylaşımını destekleyen AR-GE bütçesini oluşturulmak olarak sıralanmaktadır (Ping ve Lanteigne, 2015: 1). Bir başka ifadeyle Çin ile diğer ülkeler arasındaki kutup meseleleriyle ilgili iletişimin arttırılması önerilmektedir. Bu noktada Çin Kalkınma Bankası, yurtdışındaki projeleri finanse etmek için önemli bir kuruluş olarak kendini göstermektedir. $\mathrm{Bu}$ kuruluş öncülügünde gerçekleştirilen projeler 1şığında Çinli yetkililer, ülkenin bilimsel araştırmalar yapabileceği Kuzey Kutbu'ndaki ilişskilerini daha da güçlendirmesi gerektiğine inanmaktadır. Bunun yanında Toprak Kaynakları Bakanlığ, Devlet Okyanus İdaresi, Çin Arktik ve Antarktika Yönetimi, Polar Araştırma Enstitüsü, Polar Araştırmaları Çin Danışma Kurulu ve Dışişleri Bakanlığı Arktika'da ekonomik kalkınmanın hızlandırılması adına çalışmalar yürüten kurum ve kuruluşlar arasında stralanabilir (Tonami, 2014: 107-108). 
Arktika rotalarının geliştirilmesiyle pazarların çeşitlenmesi, yeni yatırımlara olan ihtiyac1 da beraberinde getirirken, buzullara karşı güçlendirilmiş gemiler bu yatırımların başını çekmektedir. Ancak buz sınıfı gemilerinin işletilmesi daha yüksek maliyetli olduğundan Arktika deniz taşımacilı̆ı̆ının karlllığını gündeme getirmektedir. Örneğin Çin'in Arktika'ya ilgisinin öncüsü olarak gösterilen uluslararası ölçekli CSCL ve COSCO firmalar1, ticaret yolu olarak bölgenin tercih edilmesiyle birlikte finansal zorluklarla karşı karşıya kalmışlardır ${ }^{16}$. Bu nedenle Arktika özelinde Çin'de kapsamlı bir yeniden yapılandırma sürecine ihtiyaç duyulurken, yaşanan gelişmeler birleşme yönünde tartışmaları beraberinde getirmiştir. Tabi ki Çin'de COSCO ve CSCL dışında da nakliye şirketleri mevcuttur. Örneğin Hanjin Shipping, HMM, NOL, Yang Ming ve CSAV, yakın geçmişte büyük zorluklar yaşamalarına karşın; NOL, oldukça yükssek kârlar elde etmiştir. Bu şirketler açısında buzla güçlendirilmiş gemi alımı için yüksek yatırım maliyeti; ölçek ekonomisini sınırlayan ve zamanında teslime imkân veren motor/gemi büyüklüğü gibi kısıtlamalar; küçük gemiler özelinde buza karşı dayanıklı olmamalarından dolayı Arktika’nın kârlılığı düşürmesi; fiziksel riskler ve sigorta maliyeti; bölgede faaliyet göstermenin dezavantajları arasında siralanabilir (Huang vd., 2015: 64).

\section{Arktika'nın Geleceğine Yönelik Bazı Tahminler ve Çin'in Yaklaşımı}

Küresel ssınma, son zamanlarda buzulların erimesi yoluyla yeni avlanma alanları açmış olsa da, erimeyle birlikte ortaya çıkan metan gazı biyolojik çeşitliliği olumsuz etkilemektedir. Öyle ki özellikle yerel halkın başlıca geçim kaynağı olan balıkçlık, yeni alanların ortaya çıkmasıyla bu süreçten olumlu, çevresel kirlilik nedeniyle ise olumsuz etkilenmiştir. Örneğin 1990'lı yılların sonlarında yerel halkın balıkçılığa yönelik hasatının \%18 gerilemiş olması konuya ilişkin önlemlerin alınmasını zorunlu kılmıştır. Bunun yanında uzmanlar Arktika ekonomisi için önem arz eden Ren Geyiği (Caribou) sayısındaki düşüşe de dikkat çekmekte ve yakın zamanda 450'nin altına gerilemiş olmasının bir risk unsuru olduğunu belirtmektedir. Hem balıkçlık hem de avcllık yönünde yaşanan bu kayıpların önümüzdeki dönemlerde de devam edeceği tahmin edilirken, bu sürecin zorunlu göçle sonuçlanacağ1 ve kırsal kalkınmayı olumsuz etkileyeceği öne sürülmektedir (Berman, 2004: 408). Bölge ülkelerinde özellikle deniz taşımacıllğı ve madencilik alanlarında faaliyet gösteren Çinli firmaların, Norveç kıyılarında balıkçılık yatırımlarının da olduğu düşünüldüğünde (2012-2017 yılları arasında tüm sektörlerde 2.5 milyar ABD doları), kirlenmeye yönelik etkilerin Çin'e de yansıyacağı

\footnotetext{
16 Örneğin COSCO'nun 2011 ve 2012 yllarına ait zararları, Çin'in 500 en büyük firması arasında en yüksek düzeye ulaşmışır (2011'de 1,7 milyar ABD doları, 2012'de 1,54 milyar ABD doları). CSCL ise 2011 ylı için 93 milyon ABD doları kar, 2012 ylı için 442 milyon ABD doları zarar açıklamıştır. 2013 yılının ilk yarısında ise her iki nakliye firması da zarar açıklarken, CSCL 205 milyon ABD doları, COSCO ise 165 milyon ABD doları tutarında ağır zararlarla karşı karşıya kalmışıtır (Huang vd., 2015: 64).
} 
öngörülebilir. Buradan hareketle Çinli firmaların uluslararası kuruluşlar ve antlaşmaların da etkisiyle kirliliği önleme yatırımlarını ön planda tutmaya başladıkları söylenebilir (Kirtman vd., 2013: 986).

Bununla birlikte önümüzdeki dönemlerde Kuzey'e yönelik rekreasyon faaliyetlerinde de hareketlilik beklenirken, genişleyen turizm kapasitesinin kalkınmada etkili olabileceği belirtilmektedir. Yapılan araştırmalarda özellikle çok uluslu şirketlerle rekabet edemeyen balıkçılık ve avcllık gelirleri azalan yerel halkın, turizme yönelerek alternatif yaratabileceğine ve böylelikle son dönemde hizlanan göçün önüne geçilebileceğine değinilmektedir. Bunu desteklemek için yeni karayollanı ile altyapının güçlendirilmesi gerektiği ve böylelikle eko-turizmin öne çıarılabileceği düşünülmektedir. Yakın gelecekte eko-turizm ile birlikte yol yapım ve büyük petrol kuyuları inşaatlarında da artış beklenirken, bu inşaatlara yerel unsurların dahil olması bölgesel gelişmeye olumlu yansıyacaktır. Ancak bölge halkının nitelik bakımından vasıfsız olması, büyük şirketlerin kendi ülkelerinden işçi getirmeleriyle sonuçlanmakta, bu durum ise yerel unsurların geleceği açısından risk faktörü olarak gösterilmektedir.

$\mathrm{Bu}$ gelişmelere paralel olarak 1990-2009 y1lları arasında geçen süre zarfında kış aylarında küresel ısınmadan kaynaklı yüzey aşınmaları $\% 40$ oranında hız kazanmıştır. Öyle ki geleceğe yönelik iklim senaryolarında 2080 'de sıcaklı̆̆ın 3-6 ${ }^{\circ} \mathrm{C}$ daha fazla olacağına dair çıkarımlar yapılmaktadır (Loukacheva, 2015). Söz konusu gelişme önümüzdeki dönemlerde meydana gelecek aşınmalar için de bir uyarı niteliğindedir ki örneğin 2020 yllından sonra karbon, metan ve fosil yakıt kullanımından kaynaklı emisyon artışının kütlesel buz kopmalarına yol açması beklenmektedir (Sharma vd., 2013: 961). Bununla birlikte 21. yüzyılın ortalarında Kuzey Çin'de aşırı kar yağışı olaylarının artacağ1 tahmin edilirken, 1sınmadan kaynaklı kar örüntüsünün azalacağ1 yönünde çıkarımlar yapılmaktadır (Shi vd., 2011: 2; Kirtman vd., 2013: 996). Buradan hareketle aşırı hava olaylarının yoğun yağış, düşük kar kalınlı̆̆1 şeklinde süregeldiği ve önümüzdeki dönemlerde kirliliğe yönelik önlemlerin alınmaması durumunda Çin yatırımlarının bundan olumsuz etkileneceği söylenebilir. Zira Arktika'da petrol ve türevlerine yönelik çıarma/işleme tesislerinin artması ve bunun büyük tankerler vasıtasıyla nakli, petrol sızıntısı riskini de beraberinde getirmektedir. Bu nedenle ölçek ekonomisinden faydalanan, başta Çin'e ait olmak üzere büyük ölçekli şirketler, önümüzdeki dönemlerde kıyı temizliğine yönelik faaliyetlerini arttırmayı planlamaktadır. Özellikle kirlilik açısından tüm çevrelerin dikkatini çeken Çinli firmaların, akaryakıt sızıntısını azaltmaya/önlemeye yönelik bölgesel tesislerin (ETVs ya da sığınma limanı olarak da adlandırılmaktadır) kurulmasının, çevresel kirliliği önlemek adına kaçınılmaz olduğu belirtilmektedir (Deere-Jones, 2016: 37-38). Bu da yeni maliyetler anlamına gelmektedir. 
Değinildiği üzere bölgeye yönelik yapılan araştırmalar dünyada keşfedilmemiş gazın, petrolün ve değerli madenlerin önemli bir kısmının Arktika'da yer aldığını göstermektedir. Özellikle Rusya'nın yakın bölgelerinde yoğunlaşan enerji kaynakları ile Grönland kıyı şeridinde yoğunlaşan değerli madenler, Çin'in küresel ölçekte geleceğe yönelik yatırım politikalarını etkilemektedir (Gautier vd., 2009: 1175). Örneğin 21.000 tonluk buzkıran Xue Long (Snow Dragon) ile bölgede kapsamlı araştırmaların yürütülmesini sağlamış ve yeni hedef alanların tespiti mümkün olmuştur. (Yılmaz ve Çiftçi, 2013: 10). Bunun yanında Hindistan ve Güney Kore gibi Arktika'da kıyısı bulunmamasına karşın Çin de, buzulları parçalayacak gemiler inşa etmek gibi bir takım teknolojilere ulaşmak için araştırma istasyonları kurmuştur (Grätz, 2012: 3). Çünkü Çin, gayri safi yurtiçi hasılasının (GSYH) yaklaşık yarısını deniz taşımacilığı yoluyla, üretimi için gerekli olan petrol ve gaz ithalatının yaklaşı \%70-80'ini ise siyasi açıdan istikrarsız olan Ortadoğu ve Afrika ülkelerinden sağlamaktadır (Ateş, 2017: 84). $\mathrm{Bu}$ nedenle gelecek yatırımlarını bunu ikame edecek şekilde gerçekleştirmeyi planlamaktadır ki Arktika'ya ilgi duymasının temel gerekçesi de aslinda budur.

\section{Değerlendirme}

Çin'in gayri safi yurtiçi hasıla büyüme hızı uzun yıllar çift haneli rakamlarda gerçekleştikten sonra son dönemlerde \%7'nin altına gerilemiştir. Düşen büyüme oranılla bile dünyanın en büyük ikinci ekonomisi olma özelliğini koruyan Çin ekonomisi, ABD ve Avrupa ile yapılan ticarete bağl1 olarak büyümektedir. Çin'in ihraç ettiği ürünler, ithal hammadde ve enerji kaynağı kullanılarak üretilmektedir. Dolayısıyla ekonomik büyüme ihracata, ihraç edilecek ürünlerin üretimi ise büyük ölçüde ithal girdilere bağl1 görünüm sergilemektedir. $\mathrm{Bu}$ noktada Çin, ekonomik büyümesini sürdürülebilir kilmak için hem ürettiği ürünleri hedef pazarlara daha düşük maliyetle ve daha kısa zamanda ulaştırmak istemekte, hem de ithal ettiği hammadde ve enerji kaynakları için alternatif kaynak arayışı içine girmektedir.

Yakın dönemde yaşanan küresel ısınma ve bunun yol açtı̆ı Arktika buzullarının erimesi, yeni deniz ticaret yollarını kullanılabilir hale getirmekte, dolayısıyla bu yeni ticaret yolu, Çin'in hedef pazarlara ulaşım maliyetine ve süresine olumlu yansiyacak bir unsur olarak kendini göstermektedir. Ayrıca Arktika'da önemli miktarda petrol, doğalgaz ve maden rezervleri bulunduğu tahmin edilirken, buzulların erimesinin bu kaynaklara erişimi mümkün kılması beklenmektedir. Yapılan araştırmalar dünyada henüz keşfedilmemiş gazın üçte birinin, keşfedilmemiş petrolün ise \%15'e yakınının bu bölgede yer aldığını belirtmektedir. Yaklaşık 90 milyar varil petrol, 1.669 trilyon metreküp doğalgaz, 44 milyar varil doğalgaz sıvısına karşılık gelen bu enerji kaynağının büyük çoğunluğunun deniz altında olduğu belirtilmektedir. 
Bunun yanında demir, nikel, platin, titanyum ve çinko gibi değerli metallere, minerallere ve değerli taşlara ait rezervleri barındırıyor olması da bölgenin ekonomik değerini ve önemini artırmaktadır. Enerjinin sürdürülebilirliği, buradan hareketle yeşil enerji için önemli ve gerekli görülen nadir toprak elementleri de Arktika buzullarını cazip hale getirmekte ve Çin'in bölgeye ait ilgisinin artmasını sağlamaktadır.

Hızla eriyen buzullar, Kuzey Avrupa ve Doğu Asya’yı birbirine bağlayan yaklaşı1k 7000 km'lik bir deniz yolu açmakta, Asya ve Avrupa arasında ticaret akışını sağlayan alternatif bir nakliye rotasını oluşturan bu koridor "Arktika İpek Yolu" olarak adlandırılmakta ve araştırmacılar tarafindan kıtalararası taşımacilıkta zaman ve maliyet açısından büyük bir potansiyel olarak görülmektedir. Avrupa ve Pasifik arasındaki mevcut deniz taşımacilı̆̆ güzergâhına göre $\% 40$ daha kısa mesafeye karşıllk gelen bu rota sayesinde taşıma hacminin yakın gelecekte 13 milyon ton civarına ulaşacağı tahmin edilmektedir. Bu potansiyelin farkında olan Çin, önümüzdeki yıllarda küresel ticaret için demir alacak her 6 yük gemisinden 1 tanesinin bu rotay1 kullanmasını planlamaktadır.

Bölgenin potansiyelinin farkında olan Çin ekonomisi, 2012-2017 arasındaki 6 yıllık süre zarfinda Arktika bölgesi ülkelerine yaklaşık 450 milyar ABD dolarlık yatırım yapmış ve proje başına ortalama yatırım büyüklügü 280 milyon ABD doları seviyesine ulaşmıştır. Çin'in yatırım yaptığ 1 Arktika ülkeleri arasında Rusya başı çekerken, yapılan yatırımın seviyesi Rusya ulusal gelirinin \%3'üne yaklaşmıştır. Belirtilen tarihlerde Çin'in yatırım için Rusya'dan sonra tercih ettiği diğer bölge ülkeleri sırasıyla ABD ve Kanada olmuştur. Yatırımın büyüklügü açısından Grönland'a aktarılan miktar nispi olarak her ne kadar düşük olsa da, ülkenin ulusal geliri içerisindeki payı bakımından ulaşılan seviye oldukça önemlidir. Bir başka ifadeyle özellikle demir cevheri çıkarma ve işleme faaliyetlerinin yoğunlaştı̆̆ Grönland'da yapılan Çin yatırımları, bu ülke gayri safi yurtiçi hasılasının yaklaşık \%12'sidir ki bu oldukça önemli bir seviyedir.

Sonuç olarak hammadde ve enerji temininde Çin'in dişa bağımlılığ1 dikkate alındığında, Arktika'daki yatırımlar ve işbirlikleri Çin için büyük önem arz etmektedir. Küresel 1sınmanın yol açtı̆̆ buzul erimesi, deniz taşımacıllğını ön planda tutarken, çevre örgütleri ile uluslararası kuruluşlar, maliyetlerin ve faydaların adil bir şekilde dağıtılmasını sağlamanın ancak gelecek nesillerin kullanım potansiyelini yok etmeden gerçekleştirilebileceğini vurgulamaktadır. Gelinen noktada Çin'in uluslararası toplumun iklim değişikliği konusunda harekete geçirilmesi çağrilarına olumlu cevap vermesinin ise Arktika ve dünya için sevindirici bir gelişme olduğu söylenebilir. Bunun yanında Arktika'daki ekonomik faaliyetlerin çevresel etkilerinin yaratabileceği küresel olumsuzluklara rağmen bir çekim merkezi 
yarattı̆̆ı ortadadır. Bu çekimi sınırlandırabilecek bir mekanizmanın eksikliği ise bölgedeki çevresel bozulmayı hızlandırıcı etki yaratabilecektir. 


\section{Kaynakça}

AHDR, (2004). Arctic Human Development Report. N., Einarsson, J. N. Larsen, A. Nilsson and O. R. Young (Eds.), Stefansson Arctic Institute, Akureyri, http://www.svs.is/static/files/images/pdf_files/ahdr/English_ve rsion/AHDR_first_12pages.pdf (erişim Tarihi: 10.05.2019).

AMAP (Arctic Monitoring and Assessment Programme). (2019). "Arctic Climate Change Update 2019: An Update to Key Findings of Snow, Water, Ice and Permafrost in the Arctic 2017". https://www.amap.no/documents/download/3295/inline (erişim tarihi: 19.05 .2019$)$.

AMAP (Arctic Monitoring and Assessment Programme). (2011). "Arctic Climate Issues 2011: Changes in Arctic Snow, Water, Ice and Permafrost".

https://www.amap.no/documents/download/2267/inline (erişim tarihi: 19.05 .2019$)$.

AMSA, (2009). Arctic Marine Shipping Assessment 2009 Report, Arctic Council, Norway.

Arctic Council, (2013). "Arctic Council Observer Manual For Subsidiary Bodies", Eighth Arctic Council Ministerial Meeting, Kiruna, Sweden.

Ateş, O. (2017). "Rusya Federasyonu'nun Arktika Politikası", Avrasya Incelemeleri Dergisi, 6(1): 57-95, doi: 10.26650/Jes371512.

Auerswald, D. (2019). "China's Multifaceted Arctic Sgtrategy". https://warontherocks.com/2019/05/chinas-multifaceted-arcticstrategy/ (erişim tarihi: 30.05.2019).

Brady, A.M. (2017). "China's Expanding Antarctic Interests: Implications For New Zealand", Small States And The Changing Global Order: New Zealand Faces The Future' At University Of Canterbury, , 3-4 June 2017, Christchurch New Zealand.

Berman, M., Nicolson, C., Kofinas, G, Tetlichi, J. ve Martin, S. (2004), "Adaptation And Sustainability In A Small Arctic Community: Results Of An Agent-Based Simulation Model", Arctc, 57(4): 401414.

Chen, G. (2012). "China’s Emerging Arctic Strategy". The Polar Journal, 2(2): 358-371.

Chircop, A., (2011). "The Emergence Of China As A Polar-Capable State", Canadian Naval Review, 7(1): 9-14. 
Demirkılınç, S. ve Pehlivanlı, R. (2016). "Kuzey Kutup Bölgesi'ndeki Isşbirliğinde Arktika Konseyi'nin Rolü”, 2. Uluslararası Cin'den Adriyatik'e Sosyal Bilimler Kongresi Kongre Kitabı, 5-6-7 May1s 2016, Hatay, 246-265.

Deere-Jones, T. (2016). Ecological, Economic And Social Costs Of Marine/Coastal Spills Of Fuel Oils (Refinery Residuals), European Climate Foundation, The Hague.

Descamps, M. (2019). “The Ice Silk Road: Is Chine a Near-Arctic State?”. Focus Asia, Perspective \& Analysis, February: 1-4.

EIA, (2019). China and India Accounst For Half of Global Energy Growth Throuh 2035, https://www.eia.gov/todayinenergy/detail.php?id=3130 (erişim tarihi: 01.06.2019).

Gautier, D. L., Bird, K. J., Charpentier, R. R., Grantz, A. vd. (2009). "Assessment of Undiscovered Oil and Gaz in the Arctic". Science, 324: 1175-1179, doi: 10.1126/science.1169467.

Grätz, J. (2012). "The Arctic: Thaw with Conflict Potential". CSS Analysis in Security Policy, ETH Zurich, 118, 1-4.

Hong, N. (2014). "Emerging Interests Of Non-Arctic Countries In The Arctic: A Chinese Perspective", The Polar Journal, 4(2): 271-286, doi: 10.1080/2154896X.2014.954888

Huang, L., Lasserre, F. ve Alexeeva, O. (2015). "Is China's Interest For The Arctic Driven By Arctic Shipping Potential?", Asian Geographer, 32(1): 59-71, doi:10.1080/10225706.2014.928785

IPCC, (2019). Summary For Policymakers Of IPCC Special Report On Global Warming Of $1.5^{\circ} \mathrm{C}$ Approved By Governments, https://www.ipcc.ch/2018/10/08/summary-for-policymakers-ofipcc-special-report-on-global-warming-of-1-5c-approved-bygovernments / (erişim tarihi: 25.06.2019).

Kirtman, B., S.B. Power, J.A. Adedoyin, G.J. Boer, R. Bojariu, I. Camilloni, F.J. Doblas-Reyes, A.M. Fiore, M. Kimoto, G.A. Meehl, M. Prather, A. Sarr, C. Schär, R. Sutton, G.J. van Oldenborgh, G. Vecchi ve H.J. Wang (2013), "Near-term Climate Change: Projections and Predictability". Stocker, T.F., D. Qin, G.-K. Plattner, M. Tignor, S.K. Allen, J. Boschung, A. Nauels, Y. Xia, V. Bex and P.M. Midgley (Eds.), Climate Change 2013: The Physical Science Basis. Contribution of Working Group I to the Fifth Assessment Report of the Intergovernmental Panel on Climate Change, Cambridge 
University Press, Cambridge, United Kingdom and New York, NY, USA: 953-1028.

Kopra, S. (2013). "China's Arctic Interests", Arctic Yearbook 2013, https://www.researchgate.net/publication/269109588_China's_Ar ctic_Interests (erişim tarihi: 15.04.2019).

Kwok, R. Ve Armitage T.W.K., (2017). SWOT and the Ice Covered Oceans of the Arctic and Antarctic: Sea Surface Height and Sea Ice Freeboard. Project Report, Jet Propulsion Laboratory California Institute of Technology, California.

Lanteigne, M. (2014). “Chine's Emerging Arctic Strategies: Economics and Institutions”. Institute of International Affairs, The Centre for Arctic Policy Studies Iceland, Occasional Papers.

Larsen, J. N. (2010). "Economies and Business in the Arctic Region", N. Loukacheva (Ed) Polar Law Textbook, TemaNord 2010:538, 81-100.

Loukacheva, N. (2015). "Resource Developments and Polar Law", N. Loukacheva (Eds.), Polar Law and Resources, TemaNord 2015:533, Copenhagen, 17-35.

NDRC, (2015). "Vision And Actions On Jointly Building Silk Road Economic Belt And 21st-Century Maritime Silk Road", http://en.ndrc.gov.cn/newsrelease/201503/t20150330_669367.ht $\mathrm{ml}$ (erişim tarihi: 26.06.2019).

Ping, S. ve Lanteign, M. (2015). “China’s Developing Arctic Policies: Myths And Misconceptions”, JCIR, 3(1): 1-25.

Rosen, M. E. ve Thuringer, C. B. (2017). “Unconstrained Foreign Direct Investment: An Emerging Challenge to Arctic Security”. CNA Analysis \& Solutions, Occasional Papers.

Sharma, S., Ishizawa, M., Chan, D., Lavoué, D., Andrews, E., Eleftheriadis, K. ve Maksyutov, S. (2013). " 16-Year Simulation Of Arctic Black Carbon: Transport, Source Contribution, And Sensitivity Analysis On Deposition" Journal Of Geophysucal Research: Atmospheres, 118, 943-964, doi:10.1029/2012JD017774.

Shi, X., Groisman, P.Y., D’Ery, S.J. ve Lettenmaier, D.P. (2011). "The Role Of Surface Energy Fluxes In Pan-Arctic Snow Cover Changes" Environmental Research Letters, 6-035204: 1-8.

Şahin, B., Şenol, Y. E. Ve Kartal, Ş. E., (2014). "SWOT Analysis Of Transportation In The Arctic Region", LM-SCM 2014 XII. International Logistics And Supply Chain Congress, 30-31 October 2014, İstanbul, 669-683. 
The Arctic Institute, (2019). Publications, Maps, https://www.thearcticinstitute.org/arctic-maps/ (erişim tarihi: 01.06.2019).

The State Council, (2018). China's Arctic Policy, The State Council Information Office Of The People's Republic Of China, White Paper First Edition, Beijing.

Tonami, A. (2014). "The Arctic Policy Of China and Japan: Multi-layered Economic And Strategic Motivations", The Polar Journal, 4(1): 105126, doi: 10.1080/2154896X.2014.913931

USGS (United States Geological Survey) (2008). Circum-Arctic Resource Appraisal: Estimates of Undiscovered Oil and Gas North of the Arctic Circle. Retrieved from http://pubs.usgs.gov/fs/2008/3049/fs2008-3049.pdf. (erişim tarihi: 21.05.2019)

UTIKAD (2019), Arktikte Yeni Ticaret Hatlar Açlyyor https://utikad.org.tr/Detay/Sektor-Haberleri/11301/arktikteyeni-ticaret-hatlari-aciliyor (erişim tarihi: 11.04.2019).

World Bank, (2019). "The World Bank In China", https:/ /www.worldbank.org/en/country/china/overview\#3 (erişim tarihi: 26.06.2019).

WTEx, (2019). “Crude Oil Imports by Country”, http://www.worldstopexports.com/crude-oil-imports-bycountry/ (erişim tarihi: 26.06.2019).

Xinhua. (2013). China, Russia Pledge Closer Energy Cooperation. http://news.xinhuanet.com/english/china/201302/19/c_132179010.htm (erişim tarihi: 03.04.2019).

Yılmaz, A. ve Çiftçi, A. (2013). “Arktika Bölgesi'nin Siyasal Önemi ve Siyasal ve Hukuksal Statüsünün Karşılaştırmalı Değerlendirmesi”, Muğla Sutke Kocman Üniversitesi Sosyal Bilimler Enstitïsü Dergisi, 31(Güz), 1-16. 


\section{EK 1. Arktika Bölgesi ve Arktika Devletleri}

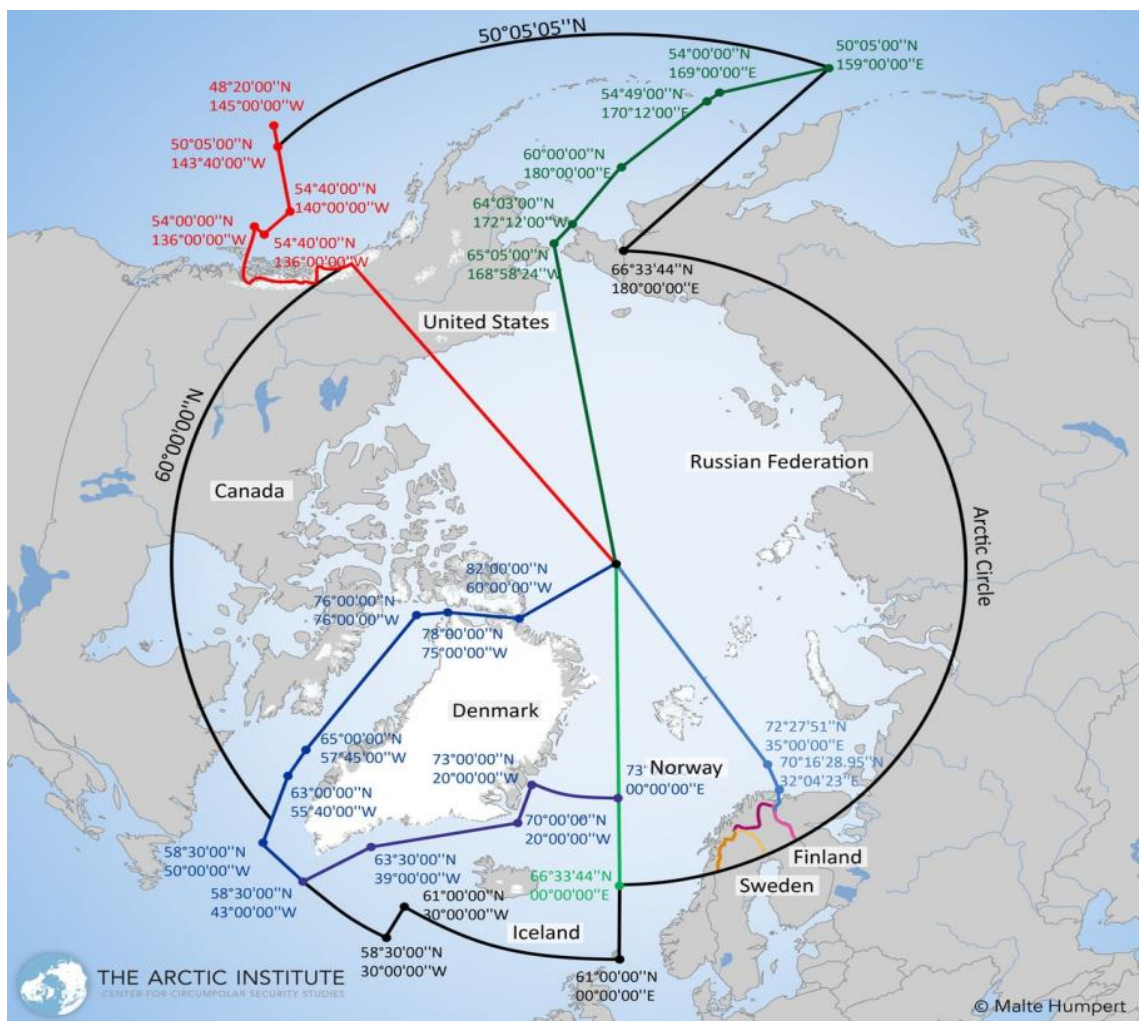

Kaynak: The Arctic Institute, 2019, https://www.thearcticinstitute.org/arcticmaps / 